\title{
Optical and geometrical properties of cirrus clouds in Amazonia derived from 1 year of ground-based lidar measurements
}

\author{
Diego A. Gouveia ${ }^{1}$, Boris Barja ${ }^{1,2,3}$, Henrique M. J. Barbosa ${ }^{1}$, Patric Seifert ${ }^{4}$, Holger Baars ${ }^{4}$, Theotonio Pauliquevis ${ }^{5}$, \\ and Paulo Artaxo ${ }^{1}$ \\ ${ }^{1}$ Applied Physics Department, Institute of Physics, University of São Paulo, São Paulo, SP, Brazil \\ ${ }^{2}$ Atmospheric Optics Group of Camagüey, Meteorological Institute of Cuba, Camagüey, Cuba \\ ${ }^{3}$ Atmospheric Research Laboratory, University of Magallanes, Punta Arenas, Chile \\ ${ }^{4}$ Leibniz Institute for Tropospheric Research (TROPOS), Leipzig, Germany \\ ${ }^{5}$ Department of Environmental Sciences, Federal University of São Paulo, Diadema, SP, Brazil \\ Correspondence to: Boris Barja (bbarja@gmail.com)
}

Received: 28 May 2016 - Discussion started: 22 June 2016

Revised: 19 February 2017 - Accepted: 23 February 2017 - Published: 15 March 2017

\begin{abstract}
Cirrus clouds cover a large fraction of tropical latitudes and play an important role in Earth's radiation budget. Their optical properties, altitude, vertical and horizontal coverage control their radiative forcing, and hence detailed cirrus measurements at different geographical locations are of utmost importance. Studies reporting cirrus properties over tropical rain forests like the Amazon, however, are scarce. Studies with satellite profilers do not give information on the diurnal cycle, and the satellite imagers do not report on the cloud vertical structure. At the same time, ground-based lidar studies are restricted to a few case studies. In this paper, we derive the first comprehensive statistics of optical and geometrical properties of upper-tropospheric cirrus clouds in Amazonia. We used 1 year (July 2011 to June 2012) of ground-based lidar atmospheric observations north of Manaus, Brazil. This dataset was processed by an automatic cloud detection and optical properties retrieval algorithm. Uppertropospheric cirrus clouds were observed more frequently than reported previously for tropical regions. The frequency of occurrence was found to be as high as $88 \%$ during the wet season and not lower than $50 \%$ during the dry season. The diurnal cycle shows a minimum around local noon and maximum during late afternoon, associated with the diurnal cycle of precipitation. The mean values of cirrus cloud top and base heights, cloud thickness, and cloud optical depth were $14.3 \pm 1.9(\mathrm{SD}) \mathrm{km}, 12.9 \pm 2.2 \mathrm{~km}, 1.4 \pm 1.1 \mathrm{~km}$, and $0.25 \pm 0.46$, respectively. Cirrus clouds were found at temperatures down to $-90^{\circ} \mathrm{C}$. Frequently cirrus were observed
\end{abstract}

within the tropical tropopause layer (TTL), which are likely associated to slow mesoscale uplifting or to the remnants of overshooting convection. The vertical distribution was not uniform, and thin and subvisible cirrus occurred more frequently closer to the tropopause. The mean lidar ratio was $23.3 \pm 8.0 \mathrm{sr}$. However, for subvisible cirrus clouds a bimodal distribution with a secondary peak at about $44 \mathrm{sr}$ was found suggesting a mixed composition. A dependence of the lidar ratio with cloud temperature (altitude) was not found, indicating that the clouds are vertically well mixed. The frequency of occurrence of cirrus clouds classified as subvisible $(\tau<0.03)$ were $41.6 \%$, whilst $37.8 \%$ were thin cirrus $(0.03<\tau<0.3)$ and $20.5 \%$ opaque cirrus $(\tau>0.3)$. Hence, in central Amazonia not only a high frequency of cirrus clouds occurs, but also a large fraction of subvisible cirrus clouds. This high frequency of subvisible cirrus clouds may contaminate aerosol optical depth measured by sun photometers and satellite sensors to an unknown extent.

\section{Introduction}

Clouds cover on average about $50 \%$ of the Earth's surface (Mace et al., 2007) and cirrus alone cover 16.7\% (Sassen et al., 2008), with higher fractions occurring in the tropics (Sassen et al., 2009). Hence cirrus are important to understand current climate and to predict future climate (Wylie et al., 2005; Stubenrauch et al., 2006; Nazaryan et al., 2008). 
Several studies emphasize the important role that cirrus clouds play in the Earth's radiation budget (i.e., Liou, 1986; Lynch et al., 2002; Yang et al., 2010a; Campbell et al., 2016). Their role is twofold. First, cirrus clouds increase warming by trapping a portion of infrared radiation emitted by the Earth/atmosphere system. Second, cirrus clouds cool the atmosphere by reflecting part of the incoming solar radiation back into space. The contribution of each effect and the net effect on the radiative forcing depends strongly on cirrus cloud optical properties, altitude, vertical and horizontal coverage (Liou, 1986; Kienast-Sjögren et al., 2016). Therefore, understanding their properties is critical to determining their impact on planetary albedo and greenhouse effects (Barja and Antuña, 2011; Boucher et al., 2013). Also, tropical cirrus clouds could influence the vertical distribution of radiative heating in the tropical tropopause layer (e.g., Yang et al., 2010b; Lin et al., 2013). Noticeably, it has been shown that an accurate representation of cirrus vertical structure in cloud radiative studies improves the results of these calculations (Khvorostyanov and Sassen, 2002; Hogan and Kew, 2005; Barja and Antuña, 2011). Recent research also shows that an increase of stratospheric water vapor is linked mainly to the occurrence of cirrus clouds in the tropical tropopause layer (TTL) (Randel and Jensen, 2013). Finally, measurements of the properties of cirrus clouds at different geographical locations are of utmost importance, potentially allowing for improvements in numerical model parameterizations and, thus, reducing the uncertainties in climatic studies.

Ground-based lidars are an indispensable tool for monitoring cirrus clouds, particularly those cirrus clouds with very low optical depth, which are undetectable for cloud radars (Comstock et al., 2002) or for passive instruments (e.g., Ackerman et al., 2008). For this reason, several studies with ground-based lidars have reported the characteristics of cirrus clouds around the globe during the last decade. There are some long-term studies reporting climatologies at midlatitudes (e.g., Sassen and Campbell, 2001; Goldfarb et al., 2001; Giannakaki et al., 2007; Hoareau et al., 2013; KienastSjögren et al., 2016) and tropical regions (e.g., Comstock et al., 2002; Cadet et al., 2003; Antuña and Barja, 2006; Seifert et al., 2007; Thorsen et al., 2011; Pandit et al., 2015). Table 1 shows an overview of these studies with different values for cirrus clouds characteristics in diverse geographical regions. There are also some short-term reports on cirrus clouds characteristics during measurement campaigns at midlatitudes (e.g., Immler and Schrems, 2002a) and tropical latitudes (Immler and Schrems, 2002b; Pace et al., 2003, and references therein). Additionally, satellite-based lidar measurements have been used to investigate the global distribution of cirrus characteristics (e.g., Nazaryan et al., 2008; Sassen et al., 2008, 2009; Wang and Dessler, 2012; Jian et al., 2015). Characteristics of tropical and subtropical cirrus clouds have similar geometrical values and they occur at higher altitudes than those at midlatitudes. However, the fre- quencies of occurrence of cirrus cloud types differ significantly between different locations.

Reports on cirrus cloud measurement over tropical rain forests like in Amazonia are scarce. Just a few global studies with satellite instruments include these regions, and they do not provide information on the diurnal cycle. There are also a few studies focused on deep convection in Amazonia that report cirrus clouds (e.g., Machado et al., 2002; Hong et al., 2005; Wendisch et al., 2016), but no lidar measurements were used. Baars et al. (2012) focused on aerosol observations with a ground-based Raman lidar, and thus report only one cirrus cloud case that was observed between 12 and $16 \mathrm{~km}$ height on 11 September 2008 during an 11-month measurement period in 2008. Barbosa et al. (2014) describe a week of cirrus cloud measurements performed from $30 \mathrm{Au}-$ gust to 6 September 2011 during an intensive campaign for calibration of the water vapor channel of the UV Raman lidar, which is also used in this study. Cirrus clouds during that period were present in $60 \%$ of the measurements. Average base and top heights were 11.5 and $13.4 \mathrm{~km}$, respectively, and average maximum backscatter occurred at $12.8 \mathrm{~km}$. Most of the time, two layers of cirrus clouds were present.

From the above discussion, the importance of continuous and long-term observations of tropical cirrus clouds is evident. In the present study, we use 1 year of ground-based lidar measurements (July 2011 to June 2012) at Manaus, Brazil to investigate the seasonal and daily cycles of geometrical (cloud top and base altitude) and optical (cloud optical depth (COD) and lidar ratio) properties of cirrus over a tropical rain forest site. In Sect. 2, a description of the Raman lidar system, dataset, processing algorithms, and site are given. The results and discussion are presented in Sect. 3. We close this paper with concluding remarks in Sect. 4.

\section{Instrumentation, dataset, and algorithms}

\subsection{Site and instrument description}

The ACONVEX (Aerosols, Clouds, cONVection EXperiment) or T0e (nomenclature of the GoAmazon2014/15 experiment, Martin et al., 2016) site is located up-wind from Manaus-AM, Brazil, at $2.89^{\circ} \mathrm{S}$ and $59.97^{\circ} \mathrm{W}$, in the central part of the Amazon Forest, as shown in the satellite image of Fig. 1. Atmospheric observations at this site began in 2011 with the objective to operate a combination of several instruments for measuring atmospheric humidity, clouds, and aerosols as well as processes which lead to convective precipitation (Barbosa et al., 2014).

As with most tropical continental sites, the diurnal cycle of precipitation is strong with a late afternoon peak (Adams et al., 2013). The precise definition of the climatological seasons varies among authors (e.g., Machado et al., 2004; Arraut et al., 2012; Tanaka et al., 2014); however, deep convection is a characteristic of the region all year. For our site and period 


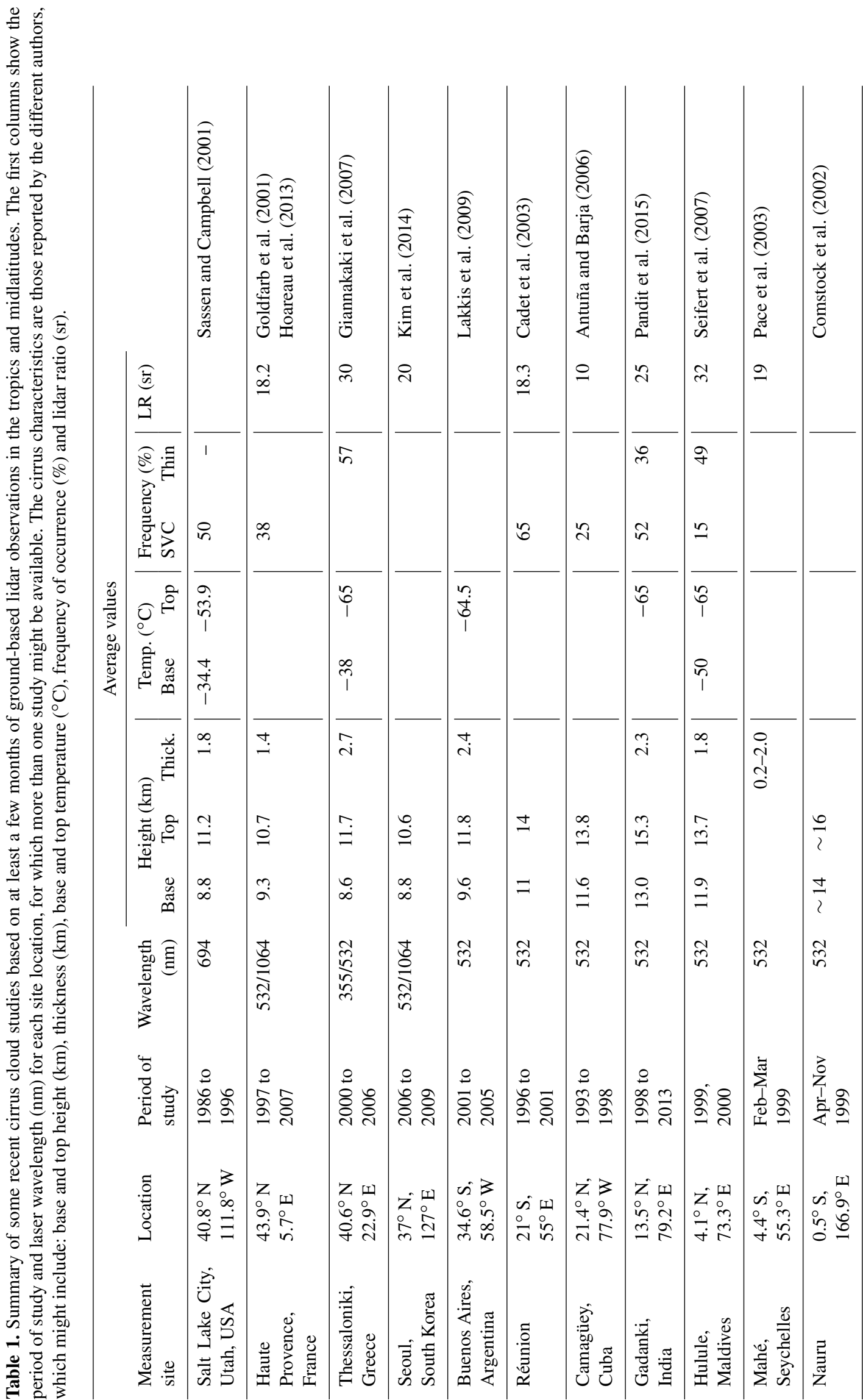




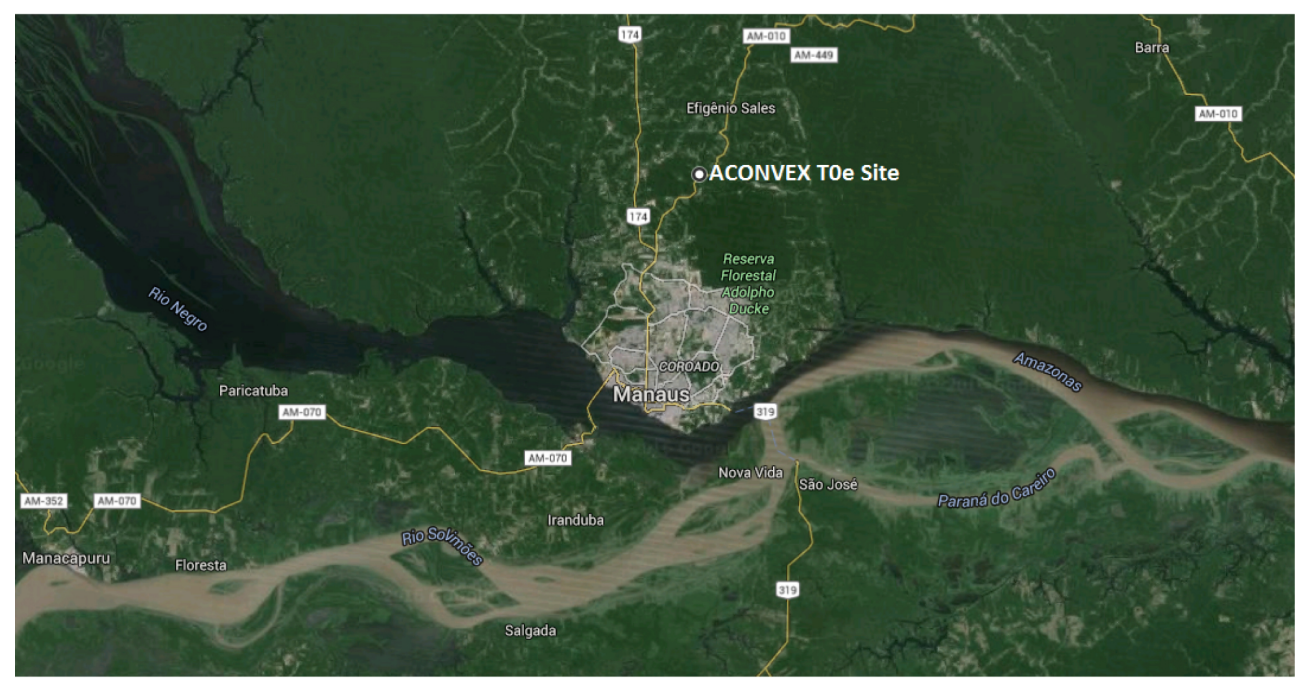

Figure 1. Satellite-based map (Google Earth) showing the location of the lidar site (ACONVEX T0e; $2.89^{\circ} \mathrm{S} 59.97^{\circ} \mathrm{W}$ ), $30 \mathrm{~km}$ upwind (north) from downtown Manaus-AM, Brazil.

of study, we considered a wet (January-April), dry (JuneSeptember), and transition (March, October-December) season respectively. Convection is more active during the wet season, when the Intertropical Convergence Zone (ITCZ) influences the region. As the ITCZ moves northward during the dry months, convective activity decreases.

The lidar system (LR-102-U-400/HP, manufactured by Raymetrics Advanced Lidar Systems) operates in the ultraviolet (UV) at $355 \mathrm{~nm}$. Three channels detect the elastically backscattered light at $355 \mathrm{~nm}$ as well as the Raman-scattered light of nitrogen $(387 \mathrm{~nm})$ and water vapor $(408 \mathrm{~nm})$, simultaneously in analog and photon-counting modes. The system is tilted by $5^{\circ}$ from the zenith to avoid specular reflection of horizontally oriented ice crystals (e.g., Westbrook et al., 2010). It is automatically operated 7 days a week, only being closed between 11:00 a.m. and 02:00 p.m. local time (LT is -4 UTC) to avoid the sun crossing the field of view. Detailed information about the lidar system and its characterization are given by Barbosa et al. (2014). To retrieve the particle backscatter and extinction profiles from the lidar signal, the temperature and pressure profiles were obtained from radio soundings launched at 00:00 and 12:00 UTC from the Ponta Pelada Airport, located $28.5 \mathrm{~km}$ to the south $\left(3.14^{\circ} \mathrm{S}\right.$, $59.98^{\circ} \mathrm{W}$ ) of the experimental site.

\subsection{Datasets}

The lidar dataset used in the present study comprises measurements recorded between July 2011 and June 2012, which were temporally averaged into $5 \mathrm{~min}$ profiles (3000 laser shoots at $10 \mathrm{~Hz}$ ). A total of 36597 profiles were analyzed corresponding roughly to one-third of the maximum possible number of profiles during 1 year.
For the long-term analysis, winds were obtained from the ERA-Interim reanalysis (Dee et al., 2011) of European Centre for Midrange Weather Forecast (ECMWF) with spatial resolution of $0.75^{\circ}$ and temporal resolution of $6 \mathrm{~h}$. The tropopause altitudes were calculated using ERA-Interim temperature profiles interpolated to the measurement time of each cirrus layer observation. We followed the definition of the World Meteorological Organization (IMV WMO, 1996) - i.e., "the lowest level at which the lapse rate decreases to $2{ }^{\circ} \mathrm{C} \mathrm{km}^{-1}$ or less, provided that the average lapse rate between this level and all higher levels within $2 \mathrm{~km}$ does not exceed $2{ }^{\circ} \mathrm{C} \mathrm{km}^{-1}$ ". We further assumed the lapse rate to vary linearly with pressure (McCalla, 1981), and the exact altitude where $\Gamma=2{ }^{\circ} \mathrm{C} \mathrm{km}^{-1}$ (i.e., the tropopause) was found by linearly interpolating between the closest available pressure levels. Precipitation was obtained from TRMM (Tropical Rainfall Measuring Mission) version 7 product 3B42 (Huffman et al., 2007) with $0.25^{\circ}$ and $3 \mathrm{~h}$ of spatial and temporal resolution, respectively. Backtrajectories were calculated using the HYSPLIT model (Stein et al., 2015) forced by meteorological fields from the US National Oceanic and Atmospheric Administration (NOAA) Global Data Assimilation System (GDAS), available at $0.5^{\circ}$ resolution.

\subsection{Cirrus cloud detection algorithm}

We used an automatic algorithm for the detection of the cloud base, the cloud top, and the maximum backscattering heights, based on Barja and Aroche (2001). The algorithm is explained in detail in Barbosa et al. (2014) and is in here only described briefly. Basically, it assumes a monotonically decreasing intensity of the lidar signal with altitude in a clear atmosphere and searches for significant abrupt changes. These abrupt changes are marked as a possible cloud base. 
Examining the signal noise, each true cloud base is discriminated. Then, the lowest altitude above cloud base with signal lower than that at cloud base and corresponding to a molecular gaseous atmosphere is determined as the cloud top. When more than one layer is present in the same profile, and their top and base are separated more than $500 \mathrm{~m}$, they are considered as individual clouds. Figure S2 in the Supplement gives an example of cloud detection. Barbosa et al. (2014) also provide information on the discrimination of false positives and the distinguishing of aerosols from thin cloud layers. After obtaining the base, top, and maximum backscatter heights, the corresponding cloud boundary temperatures are obtained from the nearest radiosonde. A detected high cloud is classified as a cirrus cloud if the cloud top temperature is lower than $-37^{\circ} \mathrm{C}$ (Sassen and Campbell, 2001; Campbell et al., 2015). These temperatures are typically found at about $10.5 \mathrm{~km}$ height over Amazonia.

\subsection{Frequency of occurrence and sampling issues}

In a simplified manner, the frequency of occurrence would just be the ratio of the number of profiles with cirrus clouds to the total number of profiles. However, while one might be sure when a cirrus cloud was detected in a given profile, there is no certainty of its presence when the profile has a low signal-to-noise ratio or when there is no measurement available. Sampling cirrus clouds with a ground-based profiling instrument can be problematic, particularly for the calculation of the temporal frequency of occurrence, due to the obscuration by lower clouds, or availability of measurements, which might introduce sampling biases (Thorsen et al., 2011).

To avoid these sampling issues, we use an approach similar to the conditional sampling proposed by Thorsen et al. (2011) and Protat et al. (2014). First, we recognize that the presence of cirrus clouds is rather independent of low-level liquid water clouds that can fully attenuate the laser beam, and independent of instrumental issues that might restrict measurement time. Hence, the best estimate of the true frequency of occurrence is the ratio of the number of profiles with cirrus, by the number of profiles where cirrus could have been detected.

These qualifying profiles are identified as follows. The noise in each clear-sky bin follows a Poisson distribution and is evaluated as the square root of the signal. The signal-tonoise ratio (SNR) is defined as the background corrected signal divided by the noise, similar to Heese et al. (2010). Profiles are selected if a clear-sky SNR higher than 1.0 is found at $16 \mathrm{~km}$, for $7.5 \mathrm{~m}$ vertical resolution. Note that this is not the SNR of the cirrus cloud ((cirrus - molecular) / noise), which typically ranges from 6 to 36 . The threshold was obtained from a performance evaluation of the detection algorithm. Using simulations, we varied cloud thickness ( $15 \mathrm{~m}$ to $4.5 \mathrm{~km}$ ), cloud backscatter coefficient (1 to $10 \mathrm{Mm}^{-1} \mathrm{sr}^{-1}$ ), and SNR (1 to 50). We found that our algorithm detects $99 \%$ of cirrus clouds with COD $>0.005$. In other words, given typical cirrus cloud optical depths, the threshold used implies a sufficiently high SNR at cloud top for applying the transmittance method (described in Sect. 2.5).

From analysis of the available profiles, 16025 were found to satisfy these criteria (see Table 2). July, August, and September, the driest months, show the highest fraction of profiles with good SNR, while the wettest months have the lowest fraction of lidar profiles with good SNR (see Fig. S1). To avoid introducing biases from the different sample sizes in different months, the frequency of occurrence for the year is calculated as the average frequency of occurrence for each season. The frequency for each season, in turn, is calculated from the frequency of each month. Finally, the frequency for each month is calculated by averaging over the mean diurnal cycles (i.e., mean of hourly means), because there are more profiles with good SNR during night compared to daytime.

\subsection{Cloud optical depth, backscattering coefficient, and lidar ratio}

Attenuation of the lidar signal by cirrus clouds can be obtained using the ratio of the range-corrected signal at the top and at the cloud base as described in Young (1995):

$\frac{S\left(z_{\mathrm{t}}\right)}{S\left(z_{\mathrm{b}}\right)}=\frac{\beta\left(z_{\mathrm{t}}\right)}{\beta\left(z_{\mathrm{b}}\right)} e^{-2 \int_{z_{\mathrm{b}}}^{z_{\mathrm{t}}} \alpha_{\mathrm{p}}\left(z^{\prime}\right) \mathrm{d} z^{\prime}} e^{-2 \int_{z_{\mathrm{b}}}^{z \mathrm{t}} \alpha_{\mathrm{m}}\left(z^{\prime}\right) \mathrm{d} z^{\prime}}$,

where $z_{\mathrm{b}}$ and $z_{\mathrm{t}}$ are the base and top height of a cirrus layer, and $S(z)=P(z) z^{2}$ is the range-corrected signal. $\beta(z)$ and $\alpha(z)$ are the volumetric backscattering and extinction coefficients, respectively, and each is the sum of a molecular (subscript $\mathrm{m}$ ) and a particle (subscript $\mathrm{p}$ ) contribution. Volumetric backscattering and extinction profiles from molecules were derived following Bucholtz (1995). Assuming a negligible aerosol contribution in the atmospheric layers just below and above the cirrus clouds (Young, 1995), we can express the transmittance factor of the lidar equation due to the cirrus layer, $T^{\text {cirrus }}$, as

$T^{\text {cirrus }}=e^{-2 \int_{z_{\mathrm{b}}}^{z_{\mathrm{t}}} \alpha_{\mathrm{p}}\left(z^{\prime}\right) \mathrm{d} z^{\prime}}=\frac{S\left(z_{\mathrm{t}}\right)}{S\left(z_{\mathrm{b}}\right)} \frac{\beta\left(z_{\mathrm{b}}\right)}{\beta\left(z_{\mathrm{t}}\right)} e^{2 \int_{z_{\mathrm{b}}}^{z_{\mathrm{t}}} \alpha_{\mathrm{m}}\left(z^{\prime}\right) \mathrm{d} z^{\prime}}$,

and the cirrus optical depth (for an example, see Fig. S2), $\tau^{\text {cirrus }}$, as

$\tau^{\text {cirrus }}=\int_{z_{\mathrm{b}}}^{z_{\mathrm{t}}} \alpha_{\mathrm{p}}\left(z^{\prime}\right) \mathrm{d} z^{\prime}=-\frac{1}{2} \ln \left(T^{\text {cirrus }}\right)$.

The accuracy of this calculation depends mainly on the SNR at the cirrus cloud altitude. However, when the lidar signal is completely attenuated by the cirrus cloud (i.e., the transmission factor approaches zero) it is impossible to obtain the true values of the cirrus top altitude and optical depth. The retrievals, in these cases called apparent values, are necessarily underestimated and were not included in our analysis (see Table 2). 
Table 2. Summary of column-integrated statistics for the total time of observation, as well as for the wet, transition, and dry seasons. Frequency of occurrence is calculated using a conditional sampling to avoid biases (Sect. 2.4). Mean cirrus cloud properties and standard deviation of the sample (in parentheses) are shown. The standard deviations of the mean were calculated and used to determine if seasonal differences (wet-dry) of the mean values are statistically significant to the $95 \%$ confidence level (indicated as *) using a two-sample $t$ test. Geometrical properties are not given because most cloud profiles have more than one layer of cirrus. Lidar ratio is calculated as a column average.

\begin{tabular}{|c|c|c|c|c|}
\hline & Total & Wet & Transition & Dry \\
\hline Observation time $(\%)^{\mathrm{a}}$ & 37.4 & 41.5 & 21.9 & 48.9 \\
\hline No. prof. measured ${ }^{b}$ & 36844 & 13828 & 7423 & 15593 \\
\hline No. prof. used in analysis ${ }^{c}$ & 16025 & 3458 & 2099 & 10468 \\
\hline No. prof. discarded for apparent top ${ }^{d}$ & 476 & 223 & 148 & 105 \\
\hline Frequency of occurrence $(\%)^{*}$ & 73.8 & 88.1 & 74.2 & 59.2 \\
\hline No. prof. w/cirrus & 11252 & 3145 & 1706 & 6397 \\
\hline Frequency of occurrence, opaque $(\%)^{*}$ & 22.6 & 31.3 & 24.6 & 11.8 \\
\hline No. prof. w/cirrus, Opaque & 3327 & 1316 & 610 & 1401 \\
\hline Frequency of occurrence, thin $(\%)^{*}$ & 32.8 & 37.9 & 36.5 & 23.9 \\
\hline No. prof. w/cirrus, thin & 4577 & 1224 & 798 & 2555 \\
\hline Frequency of occurrence, SVC $(\%)^{*}$ & 18.3 & 18.7 & 13.0 & 23.3 \\
\hline No. prof. w/cirrus, SVC & 3322 & 603 & 296 & 2423 \\
\hline Cloud optical depth* & $0.35(0.55)$ & $0.47(0.65)$ & $0.40(0.57)$ & $0.25(0.45)$ \\
\hline Max. backscatter altitude $(\mathrm{km})^{*}$ & $13.4(2.0)$ & $13.4(2.2)$ & $13.3(2.2)$ & $13.6(1.7)$ \\
\hline Temperature max. back. alt. $\left({ }^{\circ} \mathrm{C}\right)^{*}$ & $-60(15)$ & $-60(16)$ & $-59(17)$ & $-62(13)$ \\
\hline Lidar ratio $(\mathrm{sr})^{* \mathrm{e}}$ & $23.6(8.1)$ & $22.8(8.0)$ & $22.8(7.8)$ & $24.6(7.7)$ \\
\hline No. of cirrus layers per cloud prof. & $1.41(0.63)$ & $1.62(0.77)$ & $1.61(0.67)$ & $1.25(0.48)$ \\
\hline
\end{tabular}

${ }^{a}$ Fraction of observation time to total possible time $\left(21 \mathrm{~h} \mathrm{day}^{-1}\right){ }^{\mathrm{b}}$ Total number of profiles measured -i.e., not screened for low clouds or precipitation. ${ }^{c}$ Refers to the number of 5 min profiles with high enough SNR (Sect. 2.4). ${ }^{\mathrm{d}}$ Number of profiles with apparent cirrus top, considering only good profiles. ${ }^{\mathrm{e}}$ All layers in the same profile share the same average lidar ratio (LR).

The backscattering coefficients of cirrus clouds were determined by the Fernald-Klett-Sasano method (Fernald et al., 1972; Klett, 1981; Sasano and Nakane, 1984) for each 5 min averaged profile having cloud and satisfying the conditions discussed in the previous section. For retrieving extinction, the Klett method requires a predetermined value for the layer-mean lidar ratio (LR), which is the ratio between the extinction and backscattering coefficients. Then, integrating the extinction coefficient from the cloud base to cloud top, the cirrus cloud optical depth is obtained $\left(\tau_{\mathrm{Klett}}^{\text {cirrus }}\right)$. Following Chen et al. (2002), we estimated the value of LR for every cloud profile by iterating over a range of values of LR and comparing the values of $\tau_{\mathrm{Klett}}^{\text {cirus }}$ with the independent value of the cirrus optical depth obtained from the transmittance method described above $\left(\tau^{\text {cirrus }}\right)$. The cirrus mean lidar ratio is the one that minimizes the residue: $R(S)=\left(\tau_{\text {Klett }}^{\text {cirrs }}-\tau^{\text {cirrus }}\right)^{2}$. We use the approach of Chen et al. (2002) instead of the Raman method (Ansmann et al., 2002) because our instrument can only detect the Raman scattered light at nitrogen during nighttime as Raman scattering is very weak compared to the elastic scattering. Moreover, the Raman results are very noisy even during nighttime and, by analyzing simulated lidar profiles (not shown), we found that for the given setup of our study (24/7 analysis of 5 min profiles) a more precise and accurate cirrus layer-mean LR can be obtained with the Chen et al. (2002) method.
The Klett method assumes single scattering, but eventually the received photons could have been scattered by other particles multiple times before reaching the telescope. This effect, named multiple scattering, increases the apparent laser transmittance and decreases the corresponding extinction coefficient values. Inversion of uncorrected signals could bias the extinction, and hence the COD and LR, typically by 5$30 \%$ (Thorsen and $\mathrm{Fu}, 2015$ ). This is particularly important at UV wavelengths, for which a much stronger forward scattering and therefore larger amounts of multiple scattering occur compared to the visible or infrared wavelengths. For this reason, we refrain from applying empirical correction formulas (e.g., Eq. 10 in Chen et al., 2002), and instead perform a full treatment of multiple scattering following the model of Hogan (2008). The correction is found iteratively, similar to Seifert et al. (2007) and Kienast-Sjögren et al. (2016). The forward model is initialized with the originally retrieved, uncorrected extinction profile, and the model output is used to correct the extinction profile iteratively, until it converges. In our case, we assumed the effective radius of ice crystals to vary with temperature according to a climatology of aircraft measurements of tropical cirrus data (Krämer et al., 2016a, b), which includes the recent ACRIDICON field campaign with the German aircraft HALO in the Amazon region (Wendisch et al., 2016). The full treatment corrects the retrieved LR by about $40 \%$, from $16.8 \pm 5.8 \mathrm{sr}$ (uncorrected) 


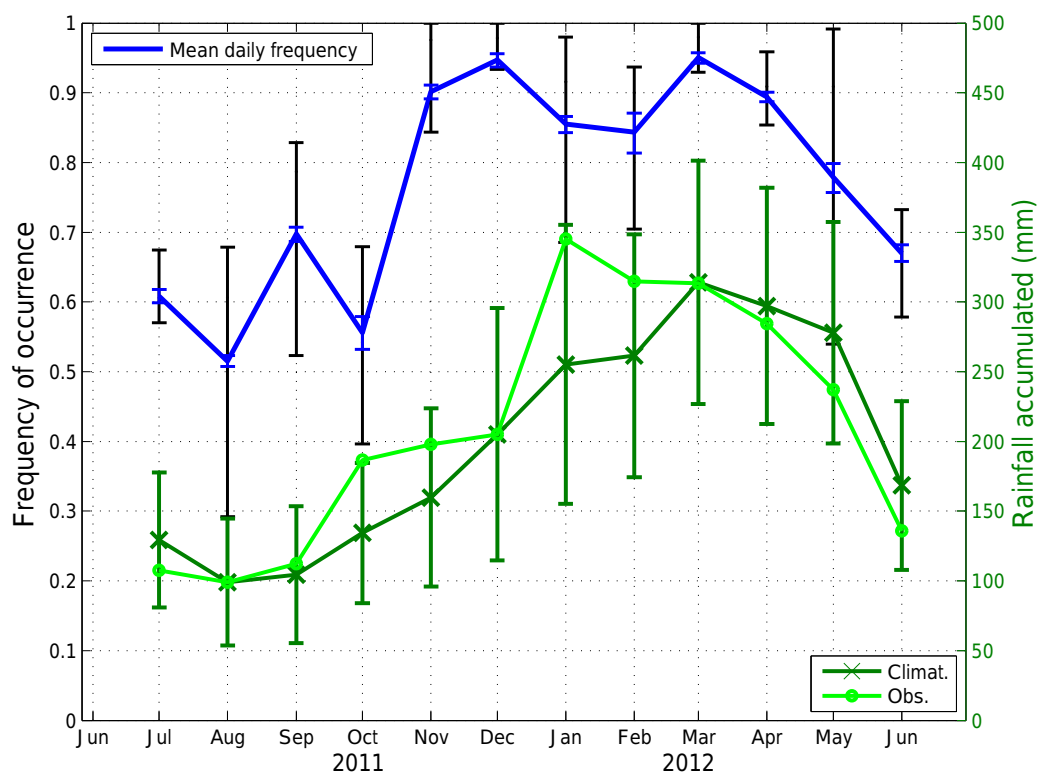

Figure 2. Monthly frequency of occurrence of cirrus clouds from July 2011 to June 2012 (blue line) with the associated statistical error (black). Accumulated (light green) and climatological (dark green) rainfall, shown on the right axis, were obtained from the TRMM $3 \mathrm{~B} 42$ version 7 dataset averaged over an area of $10^{\circ} \times 10^{\circ}$.

to $23.6 \pm 8.1 \mathrm{sr}$, while Chen's approach would only correct it to $20.2 \pm 7.0 \mathrm{sr}$. In the following sections, all cirrus optical properties (lidar ratio, extinction coefficient, and optical depth) derived in the frame of this study were corrected for multiple scattering.

\section{Results and discussion}

\subsection{Frequency of cirrus cloud occurrence}

A total of 11252 lidar profiles were recorded with the presence of cirrus clouds, yielding an average temporal frequency of cirrus cloud occurrence of $73.8 \%$ from July 2011 to June 2012. Figure 2 shows the monthly frequency of cirrus cloud occurrence, with statistical error, and precipitation in central Amazonia. There is a well-defined seasonal cycle, with maximum values from November to April, reaching $88.1 \%$ during the wet season, and a minimum value in $\mathrm{Au}-$ gust during the dry season $(59.2 \%)$, but with frequencies not lower than $50 \%$ (see Table 2). Moreover, the mean monthly cirrus cloud frequency follows the same seasonal cycle as accumulated precipitation, which responds to the seasonal changes of the ITCZ, and is higher from January to April and lower from June to September (Machado et al., 2002, 2014). Mean cirrus frequencies during the wet months are higher by a statistically significant amount than during dry months (notice the small standard deviation of the mean despite the high variability). This result and the lack of the other possible formation mechanisms proposed in the literature (Sassen, 2002) suggest that deep convection is the main formation mecha- nism for cirrus clouds in central Amazonia. Deep convective clouds generate cirrus clouds when winds in the upper troposphere remove ice crystals of the top of the large convective column, generating anvil clouds. Anvil clouds remain even after the deep convective cloud dissipates and persists from 0.5 to 3.0 days (Seifert et al., 2007).

To further investigate the role of deep convection as the main local formation mechanism, the high-altitude circulation and spatial distribution of precipitation were studied. The mean wind field at $150 \mathrm{hPa}$, approximately the mean cirrus top-cloud altitude ( $14.3 \mathrm{~km}$; see Table 3$)$, and accumulated precipitation are shown in Fig. 3. The study period was divided into wet (January, February, March, and April), dry (June, July, August, and September) and transition (May, October, November, and December) periods, based on accumulated precipitation. During the wet months, the South American monsoon is prevalent, and associated rain amounts range from 8 to $14 \mathrm{~mm} \mathrm{day}^{-1}$, with monthly totals of about $300 \mathrm{~mm}$. Winds at $150 \mathrm{hPa}$ blow from the southeast at about $6 \mathrm{~m} \mathrm{~s}^{-1}$. During the dry period, convective activity moved to the north toward Colombia and Venezuela and the $150 \mathrm{hPa}$ air flow is from the west, also at about $6 \mathrm{~m} \mathrm{~s}^{-1}$, thus allowing cirrus clouds to be advected by $520 \mathrm{~km}$ or $4.5^{\circ}$ day $^{-1}$. As previous studies reported that tropical cirrus could be transported by thousands of kilometers (e.g., Fortuin et al., 2007), $24 \mathrm{~h}$ backtrajectories were calculated to investigate the possible origin of the observed clouds. These are shown in the right panels of Fig. 3, where one trajectory was calculated for each cirrus layer detected, with the arrival height set to the height of top of the cirrus layer. Most of the trajectories are directed to the regions of maximum accumulated precip- 
Table 3. Summary of layer statistics for the total time of observation, as well as for the wet, transition, and dry seasons. Mean cirrus cloud properties and standard deviation of the sample (in parentheses) are shown. The standard deviations of the mean were calculated and used to determine if seasonal differences (wet-dry) are statistically significant to the $95 \%$ confidence level (indicated as *) using a two-sample $t$ test. Lidar ratio is calculated as a column average.

\begin{tabular}{|c|c|c|c|c|}
\hline & Total & Wet & Transition & Dry \\
\hline \multicolumn{5}{|l|}{ All layers } \\
\hline No. of cirrus layers & 15824 & 5096 & 2739 & 7989 \\
\hline Base altitude $(\mathrm{km})^{*}$ & $12.9(2.2)$ & $12.8(2.4)$ & $12.6(2.3)$ & $13.0(1.9)$ \\
\hline Top altitude (km) & $14.3(1.9)$ & $14.3(2.0)$ & $14.1(2.0)$ & $14.3(1.6)$ \\
\hline Thickness $(\mathrm{km})^{*}$ & $1.4(1.1)$ & $1.5(1.2)$ & $1.5(1.1)$ & $1.3(1.0)$ \\
\hline Cloud optical depth* & $0.25(0.46)$ & $0.30(0.52)$ & $0.26(0.47)$ & $0.20(0.40)$ \\
\hline Max. backscatter altitude $(\mathrm{km})$ & $13.6(2.0)$ & $13.7(2.3)$ & $13.5(2.2)$ & $13.6(1.8)$ \\
\hline Lidar ratio $(\mathrm{sr})^{*}$ & $23.3(8.0)$ & $22.6(8.1)$ & $22.8(7.9)$ & $24.4(7.9)$ \\
\hline Relative freq. opaque cirrus $(\%)^{*}$ & 20.5 & 25.2 & 21.0 & 17.4 \\
\hline Relative freq. thin cirrus (\%) & 37.8 & 37.0 & 43.2 & 36.5 \\
\hline Relative freq. SVC $(\%)^{*}$ & 41.6 & 37.8 & 35.8 & 46.0 \\
\hline Base above the tropopause $(\%)^{*}$ & 5.9 & 6.9 & 5.5 & 5.3 \\
\hline Top above the tropopause $(\%)^{*}$ & 15.7 & 18.7 & 16.1 & 12.9 \\
\hline \multicolumn{5}{|l|}{ Opaque layers } \\
\hline No. of opaque layers & 3251 & 1283 & 574 & 1394 \\
\hline Base altitude $(\mathrm{km})^{*}$ & $10.7(1.5)$ & $10.6(1.6)$ & $10.4(1.5)$ & $10.8(1.2)$ \\
\hline Top altitude $(\mathrm{km})$ & $13.4(1.6)$ & $13.5(1.7)$ & $13.1(1.6)$ & $13.6(1.4)$ \\
\hline Thickness $(\mathrm{km})^{*}$ & $2.76(1.02)$ & $2.84(1.07)$ & $2.65(1.04)$ & $2.73(0.94)$ \\
\hline Cloud optical depth* & $0.93(0.64)$ & $1.00(0.66)$ & $0.90(0.66)$ & $0.86(0.59)$ \\
\hline Max. backscatter altitude $(\mathrm{km})$ & $12.0(1.7)$ & $12.1(1.9)$ & $11.6(1.7)$ & $12.1(1.5)$ \\
\hline Lidar ratio $(\mathrm{sr})^{*}$ & $25.7(6.3)$ & $26.0(6.7)$ & $25.8(6.6)$ & $25.3(5.7)$ \\
\hline \multicolumn{5}{|l|}{ Thin layers } \\
\hline No. of thin layers & 5985 & 1888 & 1183 & 2914 \\
\hline Base altitude $(\mathrm{km})^{*}$ & $12.9(1.7)$ & $13.1(1.9)$ & $12.9(1.8)$ & $12.8(1.4)$ \\
\hline Top altitude $(\mathrm{km})^{*}$ & $14.4(1.7)$ & $14.6(2.0)$ & $14.4(1.8)$ & $14.3(1.4)$ \\
\hline Thickness $(\mathrm{km})^{*}$ & $1.46(0.78)$ & $1.42(0.82)$ & $1.49(0.78)$ & $1.47(0.74)$ \\
\hline Cloud optical depth & $0.12(0.07)$ & $0.12(0.07)$ & $0.12(0.07)$ & $0.11(0.07)$ \\
\hline Max. backscatter altitude $(\mathrm{km})^{*}$ & $13.7(1.7)$ & $13.9(1.9)$ & $13.7(1.9)$ & $13.5(1.5)$ \\
\hline Lidar ratio $(\mathrm{sr})^{*}$ & $22.8(7.9)$ & $21.8(7.7)$ & $21.6(7.4)$ & $24.3(8.1)$ \\
\hline \multicolumn{5}{|l|}{ SVC layers } \\
\hline No. of SVC layers & 6581 & 1924 & 980 & 3677 \\
\hline Base altitude $(\mathrm{km})^{*}$ & $14.4(1.9)$ & $14.7(2.1)$ & $14.4(2.1)$ & $14.2(1.6)$ \\
\hline Top altitude $(\mathrm{km})^{*}$ & $14.9(1.9)$ & $15.2(2.1)$ & $15.0(2.1)$ & $14.7(1.6)$ \\
\hline Thickness (km) & $0.51(0.37)$ & $0.50(0.38)$ & $0.53(0.38)$ & $0.51(0.36)$ \\
\hline Cloud optical depth & $0.011(0.008)$ & $0.011(0.008)$ & $0.012(0.009)$ & $0.011(0.008)$ \\
\hline Max. backscatter altitude $(\mathrm{km})^{*}$ & $14.6(1.9)$ & $14.9(2.1)$ & $14.7(2.1)$ & $14.4(1.6)$ \\
\hline Lidar ratio $(\mathrm{sr})^{*}$ & $21.6(8.4)$ & $19.9(7.6)$ & $21.5(8.1)$ & $23.5(9.0)$ \\
\hline
\end{tabular}

itation (left panel), which are much closer to the site during the wet $\left(\sim 5^{\circ}\right)$ than dry $\left(\sim 10^{\circ}\right)$ season. This gives further evidence that cirrus clouds observed in central Amazonia are likeliest detrained anvils from tropical deep convection.

The backward trajectories also reveal that the high-altitude circulation is quite variable. Indeed, many backward trajectories do not follow the average wind pattern and seem to point in the opposite direction of precipitation, particularly during the dry season. One should note, however, that cen- tral Amazonia still receives about $100 \mathrm{~mm} \mathrm{month}^{-1}$ of precipitation in the dry season (reddish colors around the site, Fig. 3) and most of it comes from mesoscale convective systems (Machado et al., 2004; Burleyson et al., 2016). Hence, during the dry season, there is a mixture of locally produced and long-range transported cirrus, in contrast to the wet season when there is always nearby convection.

The diurnal cycle of cirrus cloud frequency, shown in Fig. 4, also has a close relation with the convective cycle. 

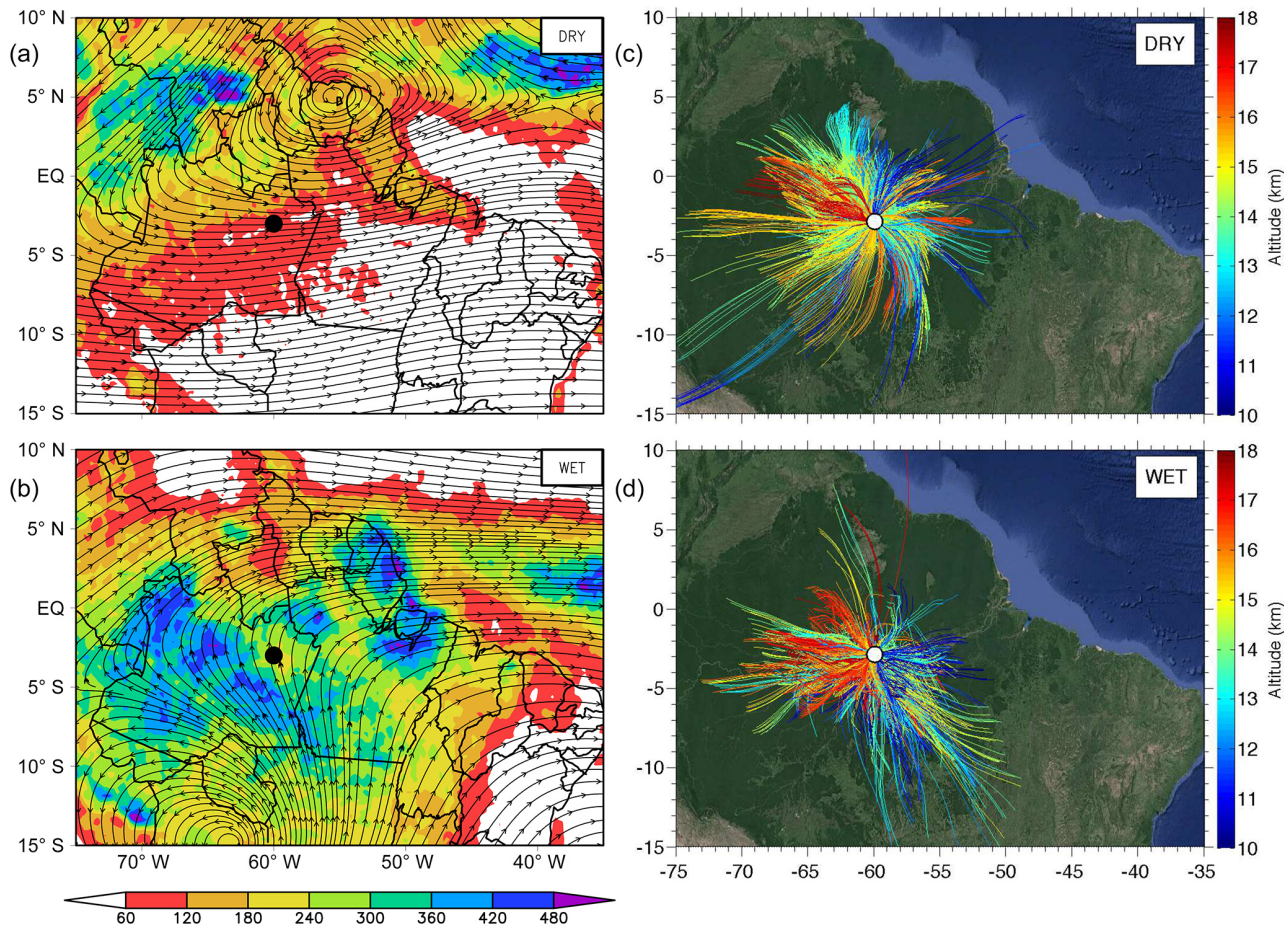

Figure 3. Panels (a, b) show mean precipitation (colors, mm month ${ }^{-1}$ ) from the TRMM $3 \mathrm{~B} 42$ version 7 and mean wind field (vectors, $\left.\mathrm{m} \mathrm{s}^{-1}\right)$ at $150 \mathrm{hPa}(\sim 14.3 \mathrm{~km})$ from ECMWF ERA-Interim reanalysis. Panels $(\mathbf{c}, \mathbf{d})$ show $24 \mathrm{~h}$ backtrajectories of air masses arriving at the site at the time and altitude that cirrus layers were detected. Results are shown separately for the dry (JJAS, a, c) and wet months (JFMA, b, d). Backward trajectories were computed using HYSPLIT model with $0.5^{\circ}$ resolution winds from GDAS/NOAA. The experimental site location is indicated in all panels with a circle.

The frequency of occurrence, for the overall period or any season, exhibits a minimum between 10:00 and 14:00 local time (LT). Maximum values are found between 17:00 and 18:00 LT, in the late afternoon, when values are slightly higher than in the morning. This diurnal variation follows the diurnal cycle of convection documented in the literature (e.g., Machado et al., 2002; Silva et al., 2011; Adams et al., 2013), as also shown in Fig. 4 as the diurnal cycle of precipitation averaged over an area of $2^{\circ} \times 2^{\circ}$ centered on the experimental site. Maximum precipitation occurs between 13:00 and 18:00 LT, during both the dry and the wet seasons, which coincides with the increase in cirrus frequency. In Fig. 4, a smaller amplitude in cirrus frequency during the wet season versus the dry season months is seen. This can be reconciled by analyzing the maximum precipitation rates and the upperaltitude circulation (see Fig. 3). When the frequency of deep convection is greater ( 3 times more in the wet season) and closer to the site $\left(\sim 5^{\circ}\right.$ in the wet and $\sim 10^{\circ}$ in the dry), the cirrus clouds, which are long-lived, presumably get more evenly distributed during the day.

To verify that the lower cirrus cloud cover around noon was not related to a decrease in SNR and, hence, a decrease in detection efficiency, we analyzed the frequency of occurrence for different cirrus types (following Sassen and Cho, 1992). Opaque $(\mathrm{COD}>0.3)$, thin $(0.3>\mathrm{COD}>0.03)$, and sub-visual cirrus $(\mathrm{SVC})$ clouds $(\mathrm{COD}<0.03)$ were considered. Their diurnal variation is also shown in Fig. 4. The frequency of occurrence of opaque cirrus has the larger amplitude, during both dry and wet seasons. During the dry (wet) season, it increases from less than 5 (20) to about $30 \%$ $(50 \%)$ in the hours following the precipitation maximum, 15:00 to 19:00 LT. The second larger diurnal variation corresponds to the occurrence frequency of thin cirrus, which decreases after the sunrise from 30 (50) to $20 \%$ (30\%) during the dry (wet) season, and increase again during nighttime, when the opaque cirrus clouds are dissipating. The SVC, whose detection could be biased by lower SNR, do not show a clear diurnal cycle. Hence, the diurnal cycle of the frequency of occurrence of cirrus clouds in central Amazonia is likely a result of the diurnal cycles of opaque and thin cirrus, which have a sufficiently high COD to not be missed by the detection algorithm.

\subsection{Geometrical, optical, and microphysical properties of cirrus clouds}

Table 2 shows column-integrated statistics of the properties of cirrus clouds during the 1-year observational period, also distinguished by season. Column-integrated COD varies from $0.25 \pm 0.45$ in the dry season to $0.47 \pm 0.65$ in the wet 

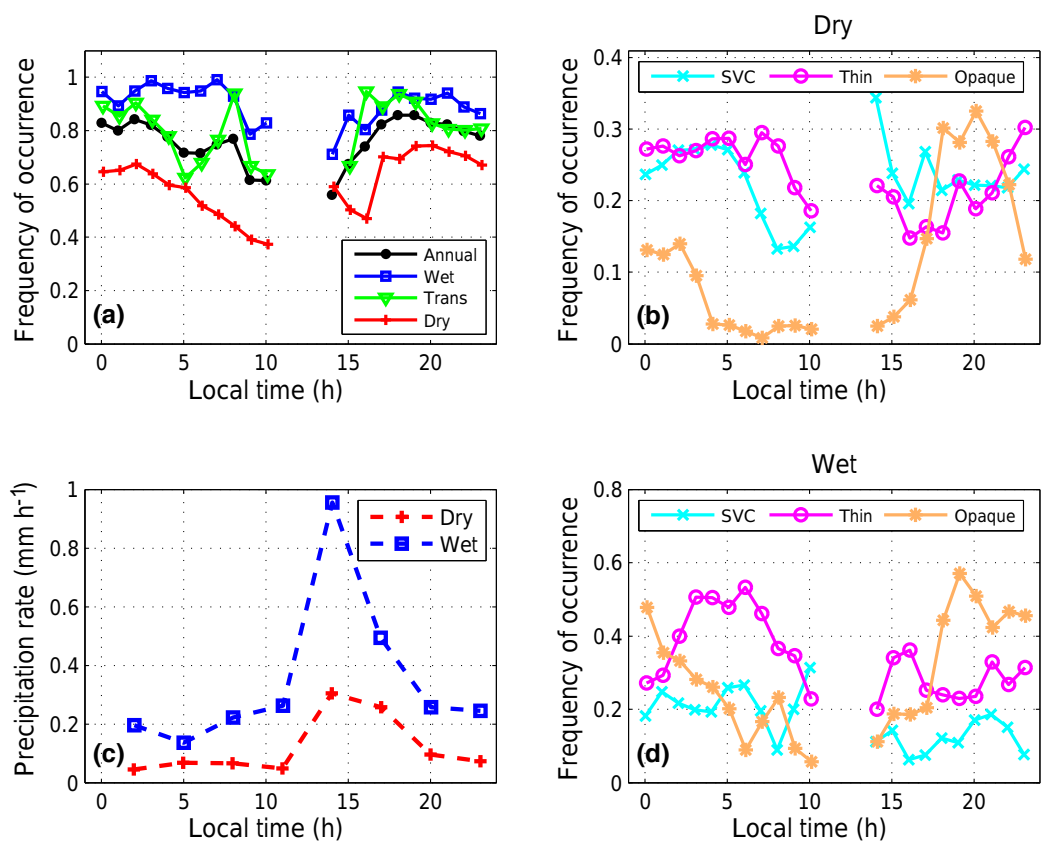

Figure 4. Panel (a) shows the daily cycles of the hourly frequency of occurrence of cirrus clouds for the annual, wet, transition, and dry periods. The same is shown for SVC, thin, and opaque cirrus clouds during the dry (b) and wet (d) seasons. Mean observed precipitation rate $\left(\mathrm{mm} \mathrm{h}^{-1}\right)$ from TRMM version 7 over an area of $2^{\circ} \times 2^{\circ}$ centered on the site, for the dry and wet periods, is given in (c).

season. The frequency of occurrence of opaque, thin, and SVC column-integrated COD is 11.8 (31.3), 23.9 (37.9), and $23.3 \%(18.3 \%)$ respectively in the dry (wet) season. The maximum backscattering altitude does not show a seasonal cycle, and is on average $13.4 \pm 2.0 \mathrm{~km}$ ( or $-60 \pm 15^{\circ} \mathrm{C}$ ). The average number of simultaneous layers of cirrus present in each cloudy profile is 1.4 (1.25 during the dry, and 1.62 during the wet season), and hence geometrical properties, in a column-integrated sense, are not discussed.

As cirrus at different altitudes might have different origins or microphysical properties, it is more important to analyze the statistics based on each layer detected, as shown in Table 3. The overall mean value for the cloud layer base altitude is $12.9 \pm 2.2 \mathrm{~km}$, for the cloud layer top altitude, $14.3 \pm 1.9 \mathrm{~km}$, and for the cloud layer geometrical thickness, $1.4 \pm 1.1 \mathrm{~km}$. The mean value of the cloud layer maximum backscattering altitude is $13.6 \pm 2.0 \mathrm{~km}$. The differences between the mean values of the geometrical properties in the dry and wet seasons are not statistically significant, except for the thickness, which changes from 1.3 to $1.5 \mathrm{~km}$, respectively. These values are similar to those reported by Seifert et al. (2007) for the Maldives $\left(4.1^{\circ} \mathrm{N}, 73.3^{\circ} \mathrm{E}\right): 11.9 \pm 1.6 \mathrm{~km}$ (base), $13.7 \pm 1.4 \mathrm{~km}$ (top), $1.8 \pm 1.0 \mathrm{~km}$ (thickness), $12.8 \pm 1.4 \mathrm{~km}$ (max. backscatter), and $-58 \pm 11^{\circ} \mathrm{C}$ (temperature at max. backscatter). Reports from subtropical regions also show similar values. Cadet et al. (2003) report for the Réunion $\left(21^{\circ} \mathrm{S}, 55^{\circ} \mathrm{E}\right)$ cirrus cloud base and top altitudes of 11 and $14 \mathrm{~km}$, respectively. Antuña and Barja (2006) report for a subtropical experimental site (Camagüey, Cuba; $21.4^{\circ} \mathrm{N}, 77.9^{\circ} \mathrm{W}$ ) cirrus cloud base and top altitudes of 11.63 and $13.77 \mathrm{~km}$, respectively. On the other hand, Sassen and Campbell (2001) show mean values for midlatitude cirrus cloud base and top of 8.79 and $11.2 \mathrm{~km}$, respectively, which is lower than for tropical cirrus, and an average geometrical thickness of $1.81 \mathrm{~km}$. Some cirrus cloud characteristics reported around the globe are shown in Table 1 for comparison.

The geometrical characteristics of the detected cirrus clouds were further examined by means of normalized histograms. Figure 5 shows the results for cloud base and top height, thickness, and cloud optical depth. Histograms for the wet and dry season months reveal differences. The cloud base distribution (Fig. 5a) is wider during the wet season. There are relatively more cirrus layers with cloud base below $12 \mathrm{~km}$ and above $16.5 \mathrm{~km}$ during the wet than during the dry season. Particularly, there is a peak centered at $16.5 \mathrm{~km}$ during wet months, which does not exist during the dry season months. The distribution of geometrical thickness (Fig. 5b) shows more cirrus layers thicker than $2 \mathrm{~km}$ (and less thinner than that) in the wet season. The normalized histogram of COD (Fig. 5d) shows relatively more cirrus layers with COD $>0.1$ in the wet season, and more with COD $<0.1$ in the dry season. The largest differences, however, are seen in the cirrus cloud top altitude distribution (Fig. 5c). It shows two peaks in the wet months, one centered at $14.25 \mathrm{~km}$ and second centered at $17.75 \mathrm{~km}$. On the other hand, for dry months, there is only one peak centered at $15.75 \mathrm{~km}$. These differences suggest different cirrus types with different origins. 

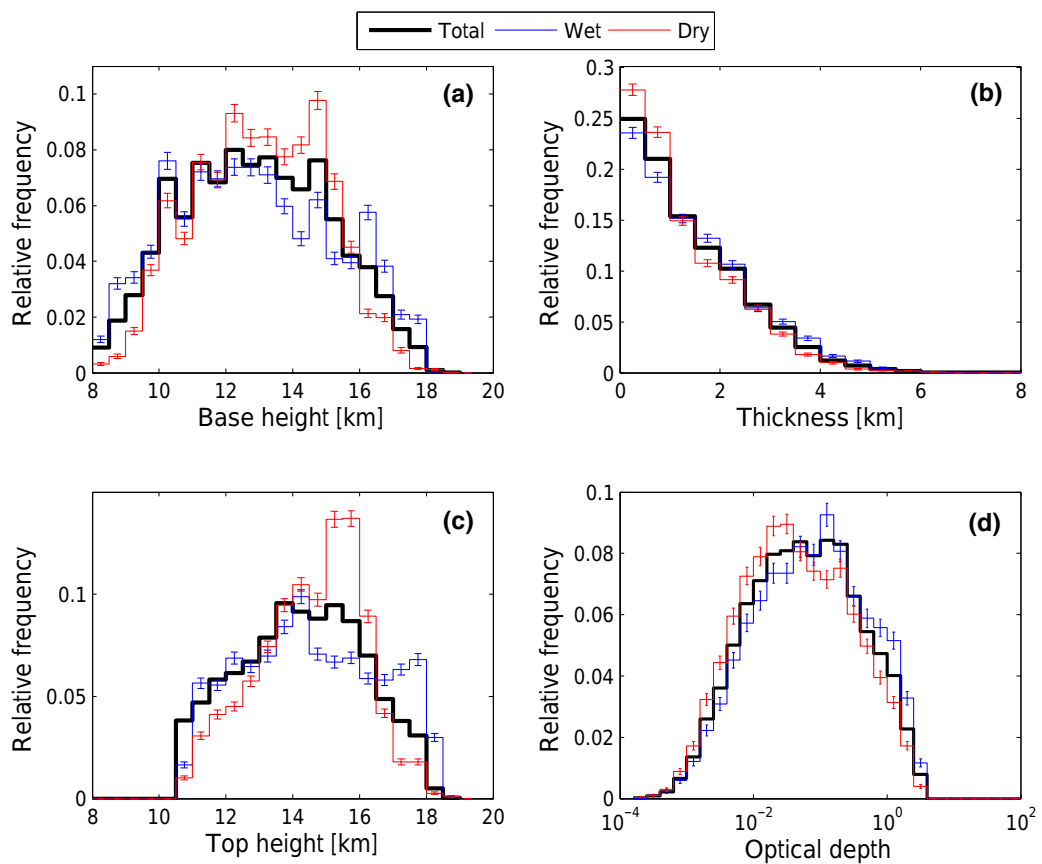

Figure 5. Panels show the normalized histograms of (a) cirrus cloud base, (b) cloud geometrical thickness, (c) cirrus cloud top, and (d) optical depth, for the overall period (black), wet season (JFMA, blue), and dry season (JJAS, red). Error bars indicate the counting statistics uncertainty.

Comstock et al. (2002) proposed two different types of cirrus clouds at Nauru in the tropical western Pacific with oceanic conditions: one type (laminar thin cirrus) with cloud base altitudes above $15 \mathrm{~km}$ and the other (geometrically thicker and more structured cirrus) with base altitudes below this height, with different characteristics. Liu and Zipser (2005) used the TRMM precipitation radar (PR) dataset to trace the deep convection and precipitation throughout the tropical zone, including oceans and continents. The authors showed that only 1.38 and $0.1 \%$ of tropical convective systems, and consequently their generated cirrus clouds, reached 14 and $16.8 \mathrm{~km}$ of altitude, respectively.

Considering these previous results, we suggest that the highest peak in wet months in cloud top distribution originates from convection penetrating the tropopause, located at about $15.9-16.5 \mathrm{~km}$, while the lowest peak is the ceiling of most tropical convection. The single peak observed during the dry months, in turn, originates from cirrus clouds transported by large distances. Clouds generated by convective systems can persist in the atmosphere from hours to days if they are slowly lifted (Ackerman et al., 1988; Seifert et al., 2007). Clouds that ascended and are horizontally transported by long distances are, in general, optically and geometrically thinner and found at higher altitudes in the troposphere. This also explains why the geometrical thicknesses and optical depth are lower during the dry season months.

To investigate whether the higher cirrus layers were indeed geometrically and optically thinner, a more in-depth analysis of the vertical distribution was performed. Figure 6 shows two-dimensional histograms of cloud optical depth and cirrus occurrence vertical distribution for the wet season months (top) and dry season months (bottom). The right panels show the vertical distribution of the frequency of occurrence for the three cirrus categories. During the wet months, there is more dispersion (wider range of COD for a fixed altitude, and vice versa) than in the dry months, which we speculate might be associated with the well-documented variability in the intensity of deep convection in Amazonia (Machado et al., 2002; Adams et al., 2009, 2013, 2015). Indeed, it is only during the wet season that a significant fraction of cirrus is found above $16 \mathrm{~km}$ height, and they have a COD ranging from 0.001 to 0.02 . Moreover, while the distribution of opaque cirrus peaks at $12 \mathrm{~km}$ height in both seasons, thin cirrus and SVC shows a bimodal distribution only in the wet season, with the highest maxima above 14 and $16 \mathrm{~km}$ respectively. This is presumably associated with the overshooting convection discussed above, which occurs mostly during the wet season (Liu and Zipser, 2005). Moreover, ice detrainment directly into the tropical tropopause layer (TTL) is one of the main mechanisms of TTL cirrus formation; the other is in situ formation by supersaturation promoted by mesoscale uplift (Cziczo et al., 2013), which can occur above tropical convective systems (Garret et al., 2004), a very common feature of the Amazon hydrological cycle.

To investigate the role of the tropopause capping on the cirrus vertical development, its altitude was calculated from 


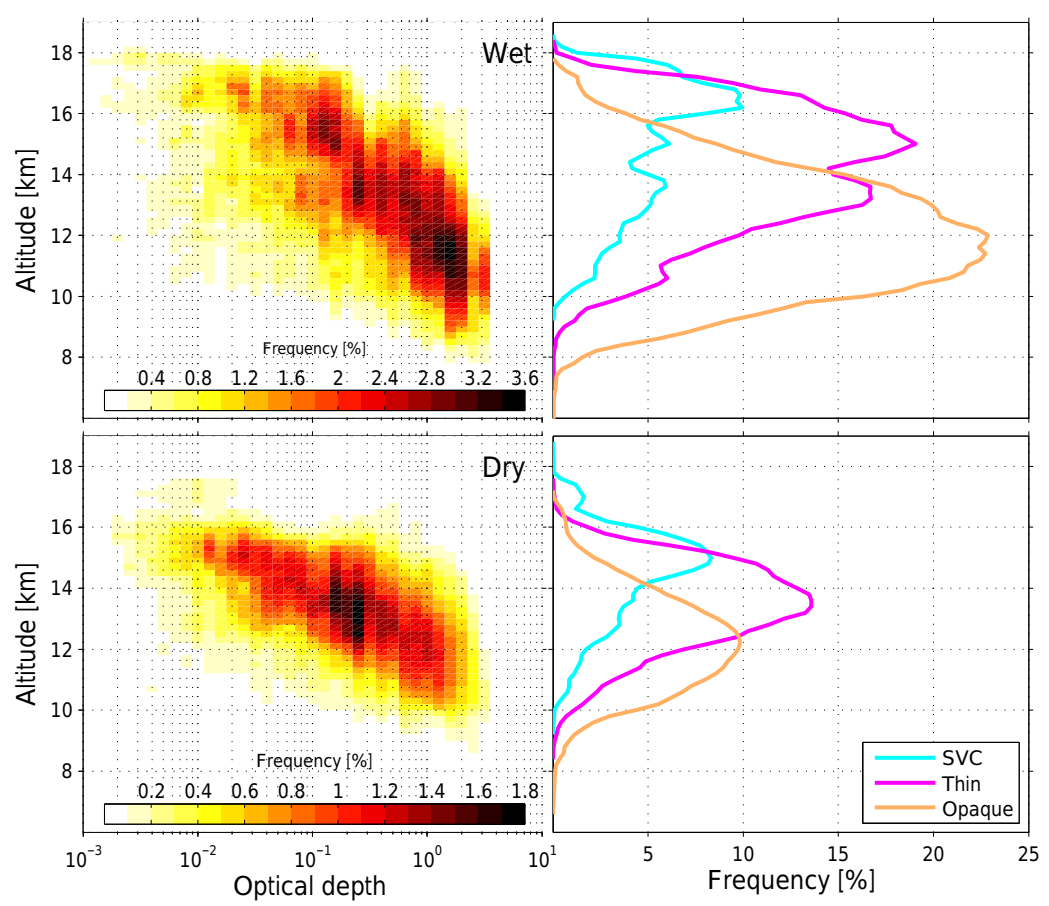

Figure 6. Two-dimensional histograms of cirrus frequency of occurrence with altitude as a function of optical depth during the wet (top) and dry (bottom) season months are shown on the left. The same is shown on the right but integrated for SVC, thin, and opaque cirrus cloud optical depths.

the ERA-Interim dataset for the observation time of each cirrus profile (see Sect. 2.2 and Fig. S3a and b). The tropopause mean altitudes during the wet, transition, and dry periods are $16.5 \pm 0.2,16.3 \pm 0.3$, and $15.9 \pm 0.4 \mathrm{~km}$, respectively. Therefore, a non-negligible fraction of the observed cirrus during the wet and dry seasons (Fig. 6) occurred likely above the tropopause. Figure 7 shows the distribution of the distance from the cloud top and bottom to the tropopause. About $7 \%(19 \%)$ of the detected cirrus clouds have their cloud base (top) above the tropopause during the wet season, and $5 \%$ (13\%) during the dry season. Most of the cirrus cloud tops are found right below the tropopause inversion, except during the wet season when they are uniformly distributed from -2 to $+0.5 \mathrm{~km}$, which is associated with the variability in deep convection intensity as discussed above. During the dry season, on the other hand, deep convection overshooting occurs primarily north of the Equator (Fig. 2 from Liu and Zipser, 2005). These cirrus that form around the tropopause cannot last for a long time (typically less than a day; Jensen et al., 1996), as they cannot be lifted above the tropopause inversion. Therefore, they cannot be transported over long distances and do not reach the measurement site, hence there is only one maximum near $15 \mathrm{~km}$ in the distribution of cloud tops, which is just below the tropopause.

The classification of cirrus clouds following Sassen and Cho (1992) shows that $41.6 \%$ of the cirrus clouds measured in our experimental site are subvisible $(\tau<0.03), 37.8 \%$ are thin cirrus $(0.03<\tau<0.3)$ and $20.5 \%$ are opaque cirrus $(\tau>0.3)$. Table 3 shows these values for each season. SVC clouds have the highest (lower) fraction during dry (wet) months. Opaque clouds have the highest (lowest) fraction during wet (dry) months, which is expected, as there is a predominance of newly generated clouds by deep convection.

This large fraction of optically thin and subvisible cirrus clouds over Amazonia present a challenge for using passive remote sensing from space, such as MODIS. As mentioned by Ackerman et al. (2010), thin cirrus clouds are difficult to detect because of insufficient contrast with the surface radiance. MODIS only detects cirrus with optical depth typically higher than 0.2 (Ackerman et al., 2008). Therefore, the MODIS's cloud-mask does not include $71 \%$ of cirrus clouds over Amazonia, and likewise, their estimation of aerosol optical depth might be contaminated with these thin cirrus. Aerosol optical depth measurements from AERONET can also be contaminated with thin cirrus clouds. Chew et al. (2011), for instance, estimated that the fraction of contaminated measurements of AERONET aerosol optical depth in Singapore $\left(1.5^{\circ} \mathrm{N}, 103.7^{\circ} \mathrm{E}\right)$ is about 0.034 to 0.060 . The determination of the actual contamination of MODIS and AERONET aerosol products for Amazonia by thin cirrus will be the subject of a forthcoming study.

The different types of cirrus clouds measured in central Amazonia, with different formation mechanisms, optical depths, and altitude ranges are expect to be composed of ice 

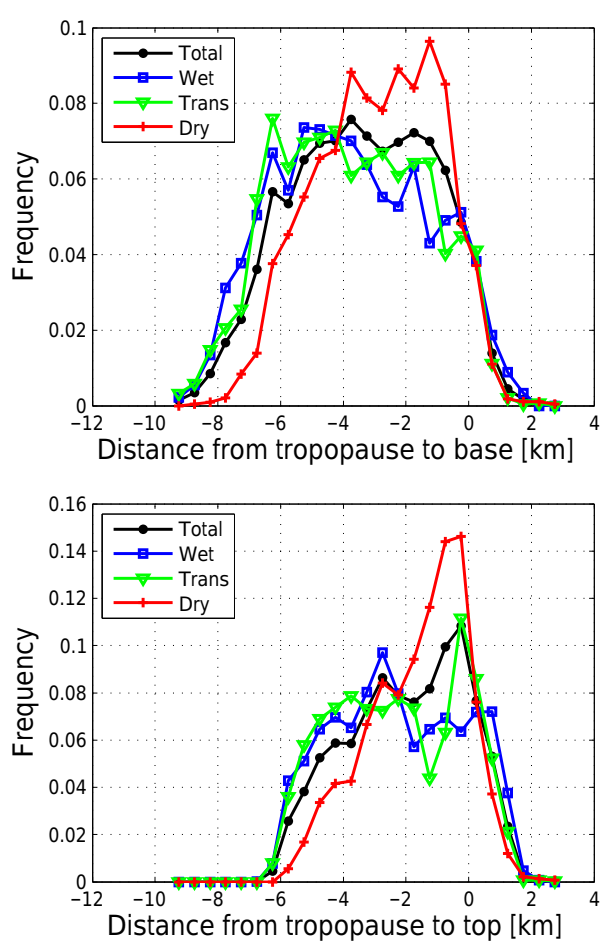

Figure 7. Normalized histograms of the distance of the tropopause to the cirrus base and top are shown for overall period (black) and each season (colors). Negative values mean that clouds are below tropopause. The average tropopause altitude was $16.2 \pm 0.4 \mathrm{~km}$.

crystals of different shapes. One way to gain information on the crystal habits is to compute the lidar ratio (Sassen et al., 1989). As explained in Sect. 2, we are able to estimate the average lidar ratio for the detected cirrus cloud layers in each profile using an interactive approach instead of explicitly calculating the extinction from the Raman signal, which would be available only during nighttime.

Average values are given in Table 3 for all cirrus, and for each category. A mean value of $23.9 \pm 8.0$ (SD) sr was obtained for the whole period and the variation is less than $1.5 \mathrm{sr}$ for the different seasons (i.e., it does not show a seasonal cycle). For opaque, thin and SVC the means are $25.7 \pm 6.3$, $22.8 \pm 7.9$, and $21.6 \pm 8.4 \mathrm{sr}$, respectively. Pace et al. (2003) found a mean value of lidar ratio of $19.6 \mathrm{sr}$ for the tropical site of Mahé, Seychelles. Seifert et al. (2007), also for tropical regions, report values close to $32 \mathrm{sr}$. Platt and Diley (1984) reported the value of $18.2 \mathrm{sr}$ with an error of $20 \%$. For the other latitudes, examples are given in Table 1 . We note, however, that the lidar ratio may vary greatly depending on the altitude and composition of cirrus clouds (Goldfarb et al., 2001), but also on the correction for multiple scattering (Platt, 1981; Hogan, 2008). The latter depends on the ice crystals effective radius, and the associated uncertainty can range from 20 to $60 \%$ (Wandinger, 1998).

Although the mean LR for all seasons and categories are similar, their statistical distribution might yet reveal differ-
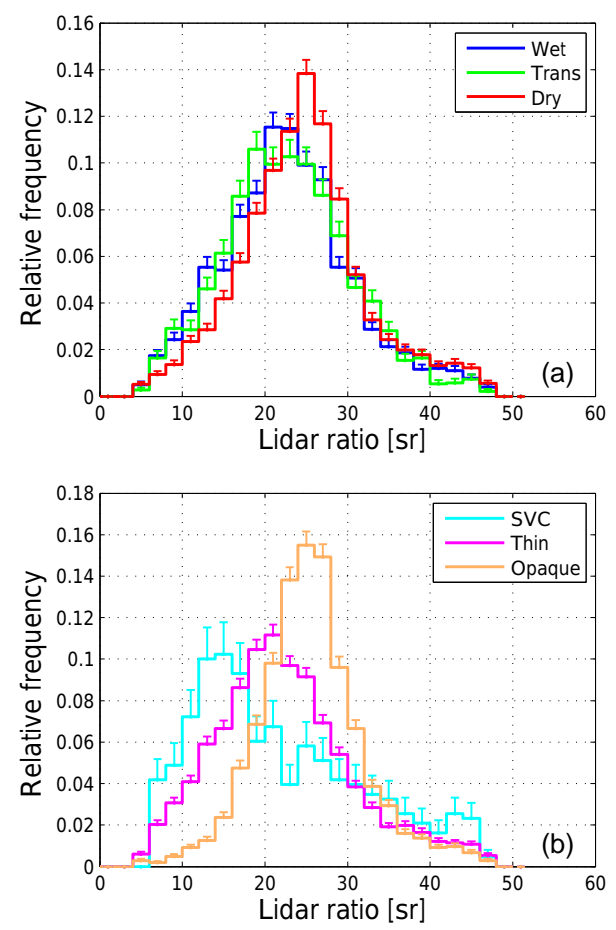

Figure 8. Normalized histograms of the lidar ratio, already corrected for multiple scattering, for the different seasons (a) and for SVC, thin, and opaque cirrus (b) are shown. Error bars indicate the counting statistics uncertainty.

ences. Figure 8 shows the histograms of lidar ratio corrected for multiple-scattering for the different seasons (top) and for the different categories (bottom). For all seasons, the most frequent lidar ratios are between 18 and $28 \mathrm{sr}$. There are notable differences only for different cirrus categories. The opaque cirrus distribution has a peak at $25 \mathrm{sr}$, while thin cirrus has its peak at about $21 \mathrm{sr}$, and SVC at about $15 \mathrm{sr}$, with a secondary peak at $44 \mathrm{sr}$.

As cirrus microphysical properties are expected to depend on altitude (e.g., Goldfarb et al., 2001), we examine the dependence of the lidar ratios with the cirrus cloud top temperature (Fig. 9). The plots show the mean, the median, and the interquartile distance. A slight increase in the lidar ratio values from 20 to $28 \mathrm{sr}$ for a decrease in temperature from -40 to $-55^{\circ} \mathrm{C}$ can be noticed during the dry period. During the wet period, the lidar ratio values are between 18 and $28 \mathrm{sr}$ in all temperature intervals. Seifert et al. (2007) and Pace et al. (2003) both show the same temperature dependence of the lidar ratio, but with different mean values of the lidar ratio. This behavior is an indication of a slight variation in the microphysical characteristics of the observed clouds.

\section{Conclusions}

One year of ground-based lidar measurements collected between July 2011 and June 2012 were used to investigate the 


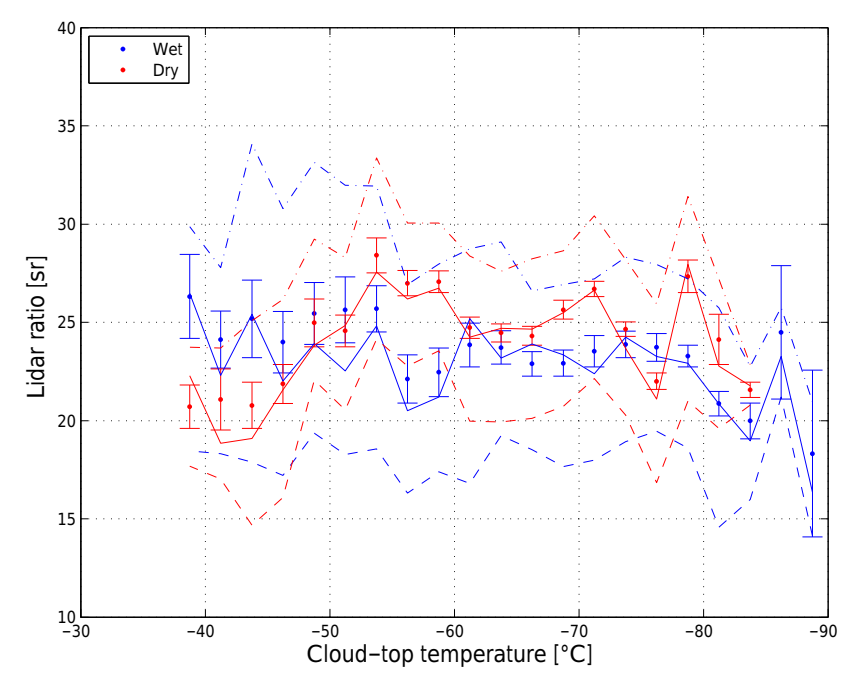

Figure 9. Dependence of the corrected lidar ratio with cloud-top temperature is shown for the wet (blue) and dry (red) seasons. The markers give mean and standard deviation of the mean. The continuous and dashed lines give median and interquartile distance. Temperature is divided into $2.5^{\circ} \mathrm{C}$ intervals.

geometrical and optical properties of cirrus clouds in central Amazonia. An algorithm was developed to search through this dataset with high vertical and temporal resolution and to automatically find clouds, calculate particle backscatter, and derive optical depth and lidar ratio. The frequency of cirrus cloud occurrence during the observation period was $73.8 \%$, which is higher than reported previously in the literature for other tropical regions. Cirrus frequency reached $88.1 \%$ during the wet months (January, February, March, and April), but decreased to $59.2 \%$ during the dry months (June, July, August, and September). Analysis of high-level circulation and precipitation during the wet months indicate that nearby deep convection was likely the main source of these cirrus, whilst during the dry period, there was a mixture of locally produced and transported clouds. Moreover, we found that the diurnal cycle of the frequency of occurrence of opaque and thin cirrus shows a minimum around 12:00 LT and a maximum around 18:00 LT, following the diurnal cycle of the precipitation for both seasons.

The geometrical and optical characteristics of cirrus clouds measured in the present study were consistent with other reports from tropical regions. The mean values were $12.9 \pm 2.2 \mathrm{~km}$ (base), $14.3 \pm 1.9 \mathrm{~km}$ (top), $1.4 \pm 1.1 \mathrm{~km}$ (thickness), and $0.25 \pm 0.46$ (optical depth). Cirrus clouds were found at temperatures down to $-90^{\circ} \mathrm{C}$ and maximum backscatter altitude was $13.6 \pm 2.0 \mathrm{~km}$.

By simultaneously analyzing cloud altitude and COD, it was found that cirrus clouds observed during the dry season months are optically thinner and lower in altitude than those during the wet period. The vertical distribution of frequency of occurrence is mono-modal, and $13 \%$ of the observed cir- rus had top within the TTL. During the wet season months, there is a wider range of COD for a fixed altitude, and vice versa, which is associated with the variability in the intensity of deep convection in Amazonia. The vertical distribution of the frequency of occurrence of the detected clouds shows a bimodal distribution for thin and SVC, and $19 \%$ of the observed cirrus had top within the TTL, which are likely associated to slow mesoscale uplifting or to the remnants of overshooting convection.

For the first time, the lidar ratio of cirrus clouds was obtained for the Amazon region. The mean lidar ratio, corrected for multiple scattering, was $23.6 \pm 8.1 \mathrm{sr}$, in agreement with other reports from the tropical regions. The statistical distribution of lidar ratios measured during the different seasons is the same, and they also do not vary with temperature (altitude) of the clouds, indicating that these are well mixed vertically. It was observed, however, that the distributions of the lidar ratio for different cirrus categories are quite different. They are more skewed towards lower lidar ratios for smaller COD. From all cirrus clouds observed, $41.6 \%$ were classified as subvisible (COD $<0.03), 37.8 \%$ as thin $(0.03<\mathrm{COD}<0.3)$ and $20.5 \%$ as opaque $(\mathrm{COD}>0.3)$. During the dry months, subvisible cirrus clouds reached a maximum frequency of occurrence of $46 \%$, while opaque cirrus have their maximum during the wet season months $(25.2 \%)$. These values are characteristic for the region under study and somewhat different from other tropical regions. Thus, central Amazonia has a high frequency of cirrus clouds in general, and a large fraction of subvisible cirrus clouds. Therefore, the aerosol optical depth determined by Sun photometers and satellite-based sensors in this region might be contaminated by the presence of these thin clouds. Future work must be conducted in order to evaluate how large this contamination might be over Amazonia.

Data availability. For access to the lidar dataset used in this study, please contact the corresponding author. Other used datasets are publicly available online: ERA-Interim reanalysis data from the ECMWF webpage (http://apps.ecmwf.int/datasets/ data/interim-full-daily/levtype $=\mathrm{sfc} /$ ) and TRMM version 7 product 3B42 from the PMM webpage (https://pmm.nasa.gov/data-access/ downloads/trmm).

\section{The Supplement related to this article is available online at doi:10.5194/acp-17-3619-2017-supplement.}

Competing interests. The authors declare that they have no conflict of interest.

Acknowledgements. We thank our colleague David K. Adams from UNAM and two reviewers for reading the manuscript and giving valuable comments. We thank Martina Krämer for sharing 
the aircraft data on tropical cirrus. Diego A. Gouveia acknowledges the support of the CNPq fellowship program. Boris Barja acknowledges the financial support of CAPES project A016_2013 on the program Science without Frontiers and the SAVERNET project. Henrique M. J. Barbosa and Paulo Artaxo acknowledge the financial support from FAPESP Research Program on Global Climate Change under research grants 2008/58100-1, 2009/15235-8, 2012/16100-1, 2013/50510-5, and 2013/05014-0. Maintenance and operation of the instruments at the experimental site would not have been possible without the institutional support from EMBRAPA. We thank INPA, The Brazilian Institute for Research in Amazonia, and the LBA Central office for logistical support. Special thanks to Marcelo Rossi, Victor Souza, and Jocivaldo Souza at Embrapa, and to Ruth Araujo, Roberta Souza, Bruno Takeshi, and Glauber Cirino from LBA. The authors gratefully acknowledge the NOAA Air Resources Laboratory (ARL) for the provision of the HYSPLIT transport and dispersion model used in this publication.

Edited by: G. Vaughan

Reviewed by: J. R. Campbell and one anonymous referee

\section{References}

Ackerman, T. P., Liou, K.-N., Valero, F. P. J., and Pfister, L.: Heating Rates in Tropical Anvils, J. Atmos. Sci., 45, 1606-1623, doi:10.1175/1520-0469(1988)045<1606:HRITA>2.0.CO;2, 1988.

Ackerman, S., Holz, R., Frey, R., and Eloranta, E.: Cloud Detection with MODIS: Part II Validation, J. Atmos. Ocean. Tech., 25, 1073-1086, doi:10.1175/2007JTECHA1053.1, 2008.

Ackerman, S., Frey, R., Strabala, K., Liu, Y., Gumley, L., Baum, B., and Menzel, P.: Discriminating Clear-Sky From Cloud With MODIS, Algorithm Theoretical Basis Document (MOD35), ATBD Version 6.1, 2010.

Adams, D. K., Souza, E., and Costa, A.: Moist Convection in Amazonia: Implications for Numerical Modeling, Revista Brasileira de Meteorologia, 13, 168-178, 2009 (in Portuguese).

Adams, D. K., Gutman, S. I., Holub, K. L., and Pereira, D. S.: GNSS observations of deep convective time scales in the Amazon, Geophys. Res. Lett., 40, 2818-2823, 2013.

Adams, D. K., Fernandes, R. M. S., Holub, K. L., Gutman, S. I., Barbosa, H. M. J., Machado, L. A. T., Calheiros, A. J. P., Bennett, R. A., Kursinski, E. R., Sapucci, L. F., DeMets, C., Chagas, G. F. B., Arellano, A., Filizola, N., Amorim Rocha, A. A., Araújo Silva, R., Assunção, L. M. F., Cirino, G. G., Pauliquevis, T., Portela, B. T. T., Sá, A., de Sousa, J. M., and Tanaka, L. M. S: The Amazon Dense GNSS Meteorological Network: A New Approach for Examining Water Vapor and Deep Convection Interactions in the Tropics, B. Am. Meteorol. Soc., 96, 2151-2165, 2015.

Ansmann, A., Riebesell, M., Wandinger, U., Weitkamp, C., Voss, E., Lahmann W., and Michaelis, W.: Combined Raman elasticbackscatter LIDAR for vertical profiling of moisture, aerosol extinction, backscatter, and LIDAR ratio, Appl. Phys., B55, 18 28, doi:10.1007/BF00348608, 1992.

Antuña, J. C. and Barja, B.: Cirrus cloud optical properties measured with lidar in Camaguiey, Cuba, Óptica Pura y Aplicada, 39, 11-16, 2006.
Arraut, J. M., Nobre, C. A., Barbosa, H. M. J., Marengo J. A., and Obregon, G.: Aerial Rivers and Lakes: looking at large scale moisture transport, its relation to Amazonia and to Subtropical Rainfall in South America, J. Climate, 25, 543-556, doi:10.1175/2011JCLI4189.1, 2012.

Baars, H., Ansmann, A., Althausen, D., Engelmann, R., Heese, B., Müller, D., Artaxo, P., Paixao, M., Pauliquevis, T., and Souza, R.: Aerosol profiling with lidar in the Amazon Basin during the wet and dry season, J. Geophys. Res., 117, D21201, doi:10.1029/2012JD018338, 2012.

Barja, B. and Aroche, R.: Cirrus clouds at Camagüey, Cuba, Proceedings of the SPARC 2000, Verrières le Buisson, France, SPARC Office, 2001.

Barja, B. and Antuña, J. C.: The effect of optically thin cirrus clouds on solar radiation in Camagüey, Cuba, Atmos. Chem. Phys., 11, 8625-8634, doi:10.5194/acp-11-8625-2011, 2011.

Barbosa, H. M. J., Barja, B., Pauliquevis, T., Gouveia, D. A., Artaxo, P., Cirino, G. G., Santos, R. M. N., and Oliveira, A. B.: A permanent Raman lidar station in the Amazon: description, characterization, and first results, Atmos. Meas. Tech., 7, 1745-1762, doi:10.5194/amt-7-1745-2014, 2014.

Boucher, O., Randall, D., Artaxo, P., Bretherton, C., Feingold, G., Forster, P., Kerminen, V.-M., Kondo, Y., Liao, H., Lohmann, U., Rasch, P., Satheesh, S. K., Sherwood, S., Stevens, B., and Zhang, X. Y.: Clouds and Aerosols, in: Climate Change 2013: The Physical Science Basis. Contribution of Working Group I to the Fifth Assessment Report of the Intergovernmental Panel on Climate Change, edited by: Stocker, T. F., Qin, D., Plattner, G.-K., Tignor, M., Allen, S. K., Boschung, J., Nauels, A., Xia, Y., Bex, V., and Midgley, P. M., Cambridge University Press, Cambridge, UK and New York, NY, USA, 2013.

Bucholtz, A.: Rayleigh-scattering calculations for the terrestrial atmosphere, Appl. Optics, 34, 2765-2773, 1995.

Burleyson, C., Feng, Z., Hagos, S., Fast, J., Machado, L., and Martin, S.: Spatial Variability of the Background Diurnal Cycle of Deep Convection around the GoAmazon2014/5 Field Campaign Sites, J. Appl. Meteorol. Clim., 55, 1579-1598, doi:10.1175/JAMC-D-15-0229.1, 2016.

Cadet, B., Goldfarb, L., Faduilhe, D., Baldy, S., Giraud, V., Keckhut, P., and Réchou, A.: A sub-tropical cirrus clouds climatology from Reunion Island $\left(21^{\circ} \mathrm{S}, 55^{\circ} \mathrm{E}\right)$ lidar data set, Geophys. Res. Lett., 30, 1130, doi:10.1029/2002GL016342, 2003.

Campbell, J. R., Vaughan, M. A., Oo, M., Holz, R. E., Lewis, J. R., and Welton, E. J.: Distinguishing cirrus cloud presence in autonomous lidar measurements, Atmos. Meas. Tech., 8, 435449, doi:10.5194/amt-8-435-2015, 2015.

Campbell, J., Lolli, S., Lewis, J., Gu, Y., and Welton, E.: Daytime Cirrus Cloud Top-of-the-Atmosphere Radiative Forcing Properties at a Midlatitude Site and Their Global Consequences, J. Appl. Meteorol. Clim., 55, 1667-1679, doi:10.1175/JAMC-D15-0217.1, 2016.

Chen, W., Chiang, C., and Nee, J.: Lidar ratio and depolarization ratio for cirrus clouds, Appl. Optics, 41, 6470-6476, 2002.

Chew, B., Campbell, J., Reid, J., Giles, D., Welton, E., Salinas, S., and Liew, S.: Tropical cirrus cloud contamination in sun photometer data, Atmos. Environ., 45, 6724-6731, 2011.

Comstock, J. M., Ackerman, T. P., and Mace, G. G.: Ground-based lidar and radar remote sensing of tropical cirrus clouds at Nauru 
Island: Cloud Statistics and radiative impacts, J. Geophys. Res., 107, 4714, doi:10.1029/2002JD002203, 2002.

Cziczo, D. J., Froyd, K. D., Hoose, C., Jensen, E. J., Diao, M., Zondlo, M. A., Smith, J. B., Twohy, C. H., and Murphy, D. M.: Clarifying the dominant sources and mechanisms of cirrus cloud formation, Science, 340, 1320-1324, doi:10.1126/science.1234145, 2013.

Dee, D. P., Uppala, S. M., Simmons, A. J., Berrisford, P., Poli, P., Kobayashi, S., Andrae, U., Balmaseda, M. A., Balsamo, G., Bauer, P., Bechtold, P., Beljaars, A. C. M., van de Berg, L., Bidlot, J., Bormann, N., Delsol, C., Dragani, R., Fuentes, M., Geer, A. J., Haimberger, L., Healy, S. B., Hersbach, H., Hólm, E. V., Isaksen, L., Kållberg, P., Köhler, M., Matricardi, M., McNally, A. P., Monge-Sanz, B. M., Morcrette, J.-J., Park, B.-K., Peubey, C., de Rosnay, P., Tavolato, C., Thépaut, J.-N. and Vitart, F.: The ERA-Interim reanalysis: configuration and performance of the data assimilation system, Q. J. Roy. Meteorol. Soc., 137, 553597, doi:10.1002/qj.828, 2011.

Fernald, F. G., Herman, B. M., and Reagan, J. A.: Determination of aerosol height distribution by lidar, Appl. Optics, 11, 482-489, 1972.

Fortuin, J. P. F., Becker, C. R., Fujiwara, M., Immler, F., Kelder, H. M., Scheele, M. P., Schrems, O., and Verver, G. H. L.: Origin and transport of tropical cirrus clouds observed over Paramaribo, Suriname $\left(5.8^{\circ} \mathrm{N}, 55.2^{\circ} \mathrm{W}\right)$, J. Geophys. Res., 112, D09107, doi:10.1029/2005JD006420, 2007.

Garrett, T. J., Heymsfield, A. J., McGill, M. J., Ridley, B. A., Baumgardner, D. G., Bui, T. P., and Webster, C. R.: Convective generation of cirrus near the tropopause, J. Geophys. Res., 109, D21203, doi:10.1029/2004JD004952, 2004.

Giannakaki, E., Balis, D. S., Amiridis, V., and Kazadzis, S.: Optical and geometrical characteristics of cirrus clouds over a Southern European lidar station, Atmos. Chem. Phys., 7, 5519-5530, doi:10.5194/acp-7-5519-2007, 2007.

Goldfarb, L., Keckhut, P., Chanin, M.-L., and Hauchecorne, A.: Cirrus climatological results from lidar measurements at OHP (44으, $6^{\circ}$ E), Geophys. Res. Lett., 28, 1687-1690, 2001.

Heese, B., Flentje, H., Althausen, D., Ansmann, A., and Frey, S.: Ceilometer lidar comparison: backscatter coefficient retrieval and signal-to-noise ratio determination, Atmos. Meas. Tech., 3, 1763-1770, doi:10.5194/amt-3-1763-2010, 2010.

Hoareau, C., Keckhut, P., Noel, V., Chepfer, H., and Baray, J.L.: A decadal cirrus clouds climatology from ground-based and spaceborne lidars above the south of France $\left(43.9^{\circ} \mathrm{N}-5.7^{\circ} \mathrm{E}\right)$, Atmos. Chem. Phys., 13, 6951-6963, doi:10.5194/acp-13-69512013, 2013.

Hogan, R. J. and Kew, S. F.: A 3D stochastic cloud model for investigating the radiative properties of inhomogeneous cirrus clouds, Q. J. Roy. Meteor. Soc., 131, 2585-2608, 2005.

Hong, G., Heygster, G., Miao, J., and Kunzi, K.: Detection of tropical deep convective clouds from AMSU-B water vapor channels measurements, J. Geophys. Res., 110, D05205, doi:10.1029/2004JD004949, 2005.

Huffman, G. J., Adler, R. F., Bolvin, D.T., Gu, G., Nelkin, E. J., Bowman, K. P., Hong, Y., Stocker, E. F., and Wolff, D. B.: The TRMM multi-satellite precipitation analysis: quasi-global, multiyear, combined-sensor precipitation estimates at fine scale, J. Hydrometeorol., 8, 38-55, 2007.
Immler, F. and Schrems, O.: LIDAR measurements of cirrus clouds in the northern and southern midlatitudes during INCA $\left(55^{\circ} \mathrm{N}\right.$, $53^{\circ} \mathrm{S}$ ): A comparative study, Geophys. Res. Lett., 29, 1809, doi:10.1029/2002GL015076, 2002a.

Immler, F. and Schrems, O.: Determination of tropical cirrus properties by simultaneous LIDAR and radiosonde measurements, Geophys. Res. Lett., 29, 2090, doi:10.1029/2002GL015076, 2002 b.

IMV WMO (International Meteorological Vocabulary WMO): No. 182. TP. 91. Geneva (Secretariat of the World Meteorological Organization) 1966. Pp. xvi, 276. Sw. fr. 40, Q. J. Roy. Meteor. Soc., 93, 148, doi:10.1002/qj.49709339524, 1996.

Jensen, E. J., Toon, O. B., Selkirk, H. B., Spinhirne, J. D., and Schoeberl, M. R.: On the formation and persistence of subvisible cirrus clouds near the tropical tropopause, J. Geophys. Res., 101, 21361-21375, doi:10.1029/95JD03575, 1996.

Jiang, J. H., Su, H., Zhai, C., Shen, T. J., Wu, T., Zhang, J., Cole, J. N. S., von Salzen, K., Donner, L. J., Seman, C., Del Genio, A., Nazarenko, L. S., Dufresne, J.-L., Watanabe, M., Morcrette, C., Koshiro, T., Kawai, H., Gettelman, A., Millán, L., Read, W. G., Livesey, N. J., Kasai, Y., and Shiotani, M.: Evaluating the diurnal cycle of upper-tropospheric ice clouds in climate models using SMILES observations, J. Atmos. Sci., 72, 1022-1044, doi:10.1175/JAS-D-14-0124.1, 2015.

Khvorostyanov, V. I. and Sassen, K.: Microphysical processes in cirrus and their impact on radiation A Mesoscale Modeling Perspective, in: Cirrus, edited by: Lynch, D., Sassen, K., Starr, D. O. C., and Stephens, G., Oxford: Oxford University Press, 397-432, 2002.

Kienast-Sjögren, E., Rolf, C., Seifert, P., Krieger, U. K., Luo, B. P., Krämer, M., and Peter, T.: Climatological and radiative properties of midlatitude cirrus clouds derived by automatic evaluation of lidar measurements, Atmos. Chem. Phys., 16, 7605-7621, doi:10.5194/acp-16-7605-2016, 2016.

Kim, Y., Kim, S.-W., Kim, M.-H., and Yoon, S.-C.: Geometric and optical properties of cirrus clouds inferred from three-year ground-based lidar and CALIOP measurements over Seoul, Korea, Atmos. Res., 139, 27-35, 2014.

Klett, J. D.: Stable analytical inversion solution for processing lidar returns, Appl. Optics, 20, 211-220, 1981.

Krämer, M., Rolf, C., Luebke, A., Afchine, A., Spelten, N., Costa, A., Meyer, J., Zöger, M., Smith, J., Herman, R. L., Buchholz, B., Ebert, V., Baumgardner, D., Borrmann, S., Klingebiel, M., and Avallone, L.: A microphysics guide to cirrus clouds - Part 1: Cirrus types, Atmos. Chem. Phys., 16, 3463-3483, doi:10.5194/acp16-3463-2016, 2016a.

Krämer, M., Afchine, A., Avallone, L., Baumgardner, D., Borrmann, S., Buchholz, B., Costa, A., Ebert, V., Fahey, D., Herman, R., Jensen, E., Klingebiel, M., Lawson, P., Woods, S., Luebke, A., Meyer, J., Rolf, C., Rollins, A., Thornberry, T., Smith, J., Spelten, N., and Zöger, M.: Microphysical properties of cirrus clouds between $75^{\circ} \mathrm{N}$ and $25^{\circ} \mathrm{S}$ derived from extensive airborne in-situ observations, in: XVII International Conference on Clouds \& Precipitation, Manchester, 2016b.

Lakkis, G. S., Lavorato, M., and Canziani, O. P.: Monitoring cirrus clouds with lidar in the Southern Hemisphere: a local study over Buenos Aires. 1. Tropopause heights, Atmos. Res., 92, 18-26, 2009. 
Lin, L., Fu, Q., Zhang, H., Su, J., Yang, Q., and Sun, Z.: Upward mass fluxes in tropical upper troposphere and lower stratosphere derived from radiative transfer calculations, J. Quant. Spectrosc. Ra., 117, 114-122, 2013.

Liou, K. N.: Influence of cirrus clouds on weather and climate processes: A global perspective, Mon. Weather Rev., 114, 11671199, 1986.

Liu, C. and Zipser, E. J.: Global distribution of convection penetrating the tropical tropopause, J. Geophys. Res., 110, D23104, doi:10.1029/2005JD006063, 2005.

Lynch, D. K., Sassen, K., Starr, D. O., and Stephens, G.: Cirrus, Oxford University Press, 480 pp., 2002.

Mace, G. G., Marchand, R., Zhang, Q., and Stephens, G.: Global hydrometeor occurrence as observed by CloudSat: Initial observations from summer 2006, Geophys. Res. Lett., 34, L09808, doi:10.1029/2006GL029017, 2007.

Machado, L. A. T., Laurent, H., and Lima, A. A.: Diurnal march of the convection observed during TRMM-WETAMC/LBA, J. Geophys. Res., 107, 8064, doi:10.1029/2001JD000338, 2002.

Machado, L. A. T., Laurent, H., Dessay, N., and Miranda, I.: Seasonal and diurnal variability of convection over the Amazonia A comparison of different vegetation types and large scale forcing, Theor. Appl. Climatol., 78, 61-77, doi:10.1007/s00704-0040044-9, 2004.

Machado, L. A. T., Silva Dias, M. A. F., Morales, C., Fisch, G., Vila, D., Albrecht, R., Goodman, S. J., Calheiros, A. J. P., Biscaro, T., Kummerow, C., Cohen, J., Fitzjarrald, D., Nascimento, E. L., Sakamoto, M. S., Cunningham, C., Chaboureau, J.-P., Petersen, W. A., Adams, D. K., Baldini, L., Angelis, C. F., Sapucci, L. F., Salio, P., Barbosa, H. M. J., Landulfo, E., Souza, R. A. F., Blakeslee, R. J., Bailey, J., Freitas, S., Lima, W. F. A., and Tokay, A.: THE CHUVA PROJECT: how does convection vary across Brazil?, B. Am. Meteorol. Soc., 1365-1380, doi:10.1175/BAMS-d-13-00084.1, 2014.

Martin, S. T., Artaxo, P., Machado, L. A. T., Manzi, A. O., Souza, R. A. F., Schumacher, C., Wang, J., Andreae, M. O., Barbosa, H. M. J., Fan, J., Fisch, G., Goldstein, A. H., Guenther, A., Jimenez, J. L., Pöschl, U., Silva Dias, M. A., Smith, J. N., and Wendisch, M.: Introduction: Observations and Modeling of the Green Ocean Amazon (GoAmazon2014/5), Atmos. Chem. Phys., 16, 47854797, doi:10.5194/acp-16-4785-2016, 2016.

McCalla, C.: Objective Determination of the Tropopause Using WMO Operational Definitions, Office Note 246, US Department of Commerce, NOAA, NWS, NMC, 18 pp., 1981.

Nazaryan, H., McCormick, M. P., and Menzel, W. P.: Global characterization of cirrus clouds using CALIPSO data, J. Geophys. Res., 113, D16211, doi:10.1029/2007JD009481, 2008.

Pace, G., Cacciani, M., di Sarra, A., Fiocco, G., and Fuà, D.: Lidar observations of equatorial cirrus clouds at Mahé Seychelles, J. Geophys. Res., 108, 4236, doi:10.1029/2002JD002710, 2003.

Pandit, A. K., Gadhavi, H. S., Venkat Ratnam, M., Raghunath, K., Rao, S. V. B., and Jayaraman, A.: Long-term trend analysis and climatology of tropical cirrus clouds using 16 years of lidar data set over Southern India, Atmos. Chem. Phys., 15, 13833-13848, doi:10.5194/acp-15-13833-2015, 2015.

Platt, C. M. R.: Remote sounding of high clouds. III: Monte Carlo calculations of multiple scattered lidar returns, J. Atmos. Sci., 38, 156-167, 1981.
Platt, C. M. R. and Diley, A. C.: Determination of the cirrus particle single scattering phase function from lidar and solar radiometric data, Appl. Opt., 23, 380-386, 1984.

Protat, A., Young, S. A., McFarlane, S. A., L'Ecuyer, T., Mace, G. G., Comstock, J. M., Long, C. N., Berry, E., and Delano, J.: Reconciling Ground-Based and Space-Based Estimates of the Frequency of Occurrence and Radiative Effect of Clouds around Darwin, Australia, J. Appl. Meteor. Clim., 53, 456-478, doi:10.1175/JAMC-D-13-072.1, 2014.

Randel, W. J. and Jensen, E. J.: Physical processes in the tropical tropopause layer and their roles in a changing climate, Nat. Geosci., 6, 169-176, doi:10.1038/ngeo1733, 2013.

Sasano, Y. and Nakane, H.: Significance of the extinction/backscatter ratio and the boundary value term in the solution for the two-component lidar equation, Appl. Optics, 23, 11-13, 1984.

Sassen, K.: Cirrus Clouds. A Modern Perspective, in: Cirrus, edited by: Lynch, D., Sassen, K., Starr, D. O'C., and Stephens, G., Oxford University Press, 136-146, 2002.

Sassen, K. and Campbell, J. R.: A midlatitude cirrus cloud climatology from the facility for atmospheric remote sensing. Part I: Macrophysical and synoptic properties, J. Atmos. Sci., 58, 481496, 2001.

Sassen, K. and Cho, B. S.: Subvisual/thin cirrus dataset for satellite verification and climatological research, J. Appl. Meteorol., 31, 1275-1285, 1992.

Sassen, K., Starr, D. O'C., and Uttal, T.: Mesoscale and Microscale Structure of Cirrus Clouds: Three Case Studies, J. Atmos. Sci., 46, 371-396, 1989.

Sassen, K., Wang, Z., and Liu, D.: Global distribution of cirrus clouds from CloudSat/Cloud-Aerosol Lidar and Infrared Pathfinder Satellite Observations (CALIPSO) measurements, J. Geophys. Res., 113, D00A12, doi:10.1029/2008JD009972, 2008.

Sassen, K., Wang, Z., and Liu, D.: Cirrus clouds and deep convection in the tropics: Insights from CALIPSO and CloudSat, J. Geophys. Res., 114, D00H06, doi:10.1029/2009JD011916, 2009.

Seifert, P., Ansmann, A., Muâller, D., Wandinger, U., Althausen, D., Heymsfield, A. J., Massie, S. T., and Schmitt, C.: Cirrus optical properties observed with lidar, radiosonde and satellite over the tropical indian ocean during the aerosol-polluted northeast and clean maritime southwest monsoon, J. Geophys. Res., 112, D17205, doi:10.1029/2006JD008352, 2007.

Silva, V. B. S., Kousky, V. E., and Higgins, R. W.: Daily Precipitation Statistics for South America: An Intercomparison between NCEP Reanalyses and Observations, J. Hydrometeorol., 12, 101-117, doi:10.1175/2010JHM1303.1, 2011.

Stein, A. F., Draxler, R. R., Rolph, G. D., Stunder, B. J. B., Cohen, M. D., and Ngan, F.: NOAA's HYSPLIT atmospheric transport and dispersion modeling system, B. Am. Meteorol. Soc., 96, 2059-2077, doi:10.1175/BAMS-D-14-00110.1, 2015

Stubenrauch, C. J., Chédin, A., Rädel, G., Scott, N. A., and Serrar, S.: Cloud Properties and Their Seasonal and Diurnal Variability from TOVS Path-B, J. Climate, 19, 5531-5553, 2006.

Tanaka, L. M. d. S., Satyamurty, P., and Machado, L. A. T.: Diurnal variation of precipitation in central Amazon Basin, Int. J. Climatol., 34, 3574-3584, doi:10.1002/joc.3929, 2014. 
Thorsen, T. and Fu, Q.: Automated Retrieval of Cloud and Aerosol Properties from the ARM Raman Lidar. Part II: Extinction, J. Atmos. Ocean. Tech., 32, 1999-2023, doi:10.1175/JTECH-D-14$00178.1,2015$.

Thorsen, T. J., Qiang, F., and Comstock, J. M.: Comparison of the CALIPSO satellite and ground-based observations of cirrus clouds at the ARM TWP sites, J. Geophys. Res., 116, D21203, doi:10.1029/2011JD015970, 2011.

Wandinger, U.: Multiple-scattering influence on extinction- and backscatter-coefficient measurements with Raman and highspectral-resolution lidars, Appl. Optics, 37, 417-427, 1998.

Wang, T. and Dessler, A. E.: Analysis of cirrus in the tropical tropopause layer from CALIPSO and MLS data: A water perspective, J. Geophys. Res., 117, D04211, doi:10.1029/2011JD016442, 2012.

Wendisch, M., Pöschl, U., Andreae, M. O., Machado, L. A. T., Albrecht, R., Schlager, H., et al.: The ACRIDICON-CHUVA campaign: Studying tropical deep convective clouds and precipitation over Amazonia using the new German research aircraft HALO, B. Am. Meteorol. Soc., 97, 1885-1908, doi:10.1175/BAMS-D14-00255.1, 2016.
Westbrook, C. D., Illingworth, A. J., O'Connor, E. J., and Hogan, R. J., Doppler lidar measurements of oriented planar ice crystals falling from supercooled and glaciated layer clouds, Q. J. Roy. Meteor. Soc., 136, 260-276, 2010.

Wylie, D. P., Jackson, D. L., Menzel, W. P., and Bates, J. J.: Trends in global cloud cover in two decades of HIRS observations, J. Climate, 18, 3021-3031, 2005.

Yang, P., Hong, G., Dessler, A. E., Ou, S. C., Liou, K. N., Minnis, P., and Hashvardhan,: Contrails and induced cirrus: Optics and radiation, B. Am. Meteorol. Soc., 91, 473-478, 2010 a.

Yang, Q., Fu, Q., and Hu, Y.: Radiative impacts of clouds in the tropical tropopause layer, J. Geophys. Res., 115, D00H12, doi:10.1029/2009JD012393, 2010b.

Young, S.: Analysis of lidar backscatter profiles in optically thin cirrus, Appl. Optics, 34, 7019-7031, 1995. 